\title{
Badania i konserwacja ikony Św. Jozafat biskup biełogorodzki z rekonstrukcją pozłoty i puncowań
}

\author{
DANUTA STĘPIEŃ \\ Wydział Konserwacji i Restauracji Dzieł Sztuki \\ Akademia Sztuk Pięknych w Warszawie \\ e-mail: danuta.stepien@cybis.asp.waw.pl \\ ORCID: 0000-0002-8199-4806
}

Keywords: Icon, research techniques, conservation, pigments, paint layers, gilding, puncturing

Słowa kluczowe: Ikona, Św. Józafat biskup biełogorodzki, malarstwo rosyjskie XIX wieku, konserwacja malowidła

\section{Abstract}

\section{The Research and Conservation of the Icon St. Josaphat, Bishop of Belgorod with} a Reconstruction of Gilding and Puncturing

The scientific objective of the research task was the conservation, with full reconstruction, of the icon St. Josaphat, Bishop of Belgorod, and to carry out interdisciplinary research into the iconographer's workshop. The technological layers were determined, the technique and technology of painting were analyzed, and the reconstruction of the missing elements of the work was documented.

Thanks to examinations under the microscope and an analysis of a sample of wood taken from the base, we know that the base is of alder (Alnus). Organoleptic tests and tests with instruments permit the conclusion that the icon was painted using the tempera technique on a chalk-plaster ground (lefkas), on which gilding was made (a silver-gold flake called a bipedal used in iconic painting since the 14th century) on a red bolus background.

The flesh-coloured and red layers of paint contain: lead white with the addition of barite white (?), iron red, organic red, cinnabar and umbrae. The blues were painted by using ultramarine, Prussian blue, organic blue (?), green chromate (a mixture of Prussian blue and yellow chromate - lead chromate). 
Dr. Katarzyna Wantuch-Jarkiewicz and Dr. Mirosław Wachowiak tested the elemental composition of the paint layers, the composition of the ground and the type of yellows, using the non-invasive XRF method. An analysis based on samples taken from the icon: the stratigraphic structure, the pigments used, the fillers in the plaster and the type of wood in the base, was carried out at the Chair of Specialist Examinations and Documentation Techniques of the Department of Conservation and Restoration of Works of Art of the Academy of Fine Arts in Warsaw. The tests were performed by Dr. Anna Nowicka, Dr. Elżbieta Jeżewska and Marek Wróbel.

By establishing the icon's content and the manner of presenting it, we obtain valuable information about the workshop and about the period in which the work was created. The results of our research enhance our knowledge of the iconographer's workshop and are helpful in attributing similar artworks to a specific workshop and dating them.

\section{Abstrakt}

Konserwację i restaurację ikony Św. Jozafat biskup biełogorodzki ze zbiorów prywatnych wykonano w ramach projektu badawczego ASP/WK/19/PB. Celem naukowym zadania badawczego była konserwacja dzieła z pełną jej rekonstrukcją oraz przeprowadzenie interdyscyplinarnych badań warsztatu ikonopisarza. Prace poprzedzające zabiegi konserwatorskie obejmowały analizę wszystkich warstw technologicznych ikony.

Omawiana w artykule ikona od dawna nie stanowi obiektu kultu; jest pamiątką z podróży jej właścicielki do Petersburga. Opracowanie programu konserwatorskiego zależało od stanu zachowania i przeznaczenia obrazu - w założeniu celem było przywrócenie jego pierwotnego wyglądu. Ikona ze św. Jozafatem ma bogatą strukturę, w związku z tym starano się, aby wszystkie elementy, które się na nią składają technika wykonania, predyspozycje twórcy, kontekst społeczny, a nawet ślady czasu oraz zastosowane narzędzia i materiały - były czytelne. Ponieważ ikonę poddano konserwacji około pięćdziesięciu lat temu, obecnie wszelkie czynności można było podjąć po rozpoznaniu, które warstwy są dodane do oryginału, które zniszczenia są wynikiem czynników atmosferycznych, mechanicznych, a jakie powstały wewnątrz struktury materii malarskiej z upływem czasu.

Zgodnie z głównym zadaniem konserwatorskim, poprawiono stan zachowania ikony przez przywrócenie integralności technologicznej oraz artystyczno-estetycznej sakralnemu przedstawieniu. Rozpoznano warsztat nieznanego ikonopisarza. Z przeprowadzonych badań wynika, że malarz tworząc ikonę łączył dawne szlachetne pigmenty mineralne, takie jak ultramaryna i cynober, z później wprowadzonymi chromianami, których przemysłowa produkcja przypada na okres pomiędzy końcem XVIII i pierwszymi dziesięcioleciami XIX wieku. Z kolei na podstawie analizy warsztatu oraz estetyki malowania należałoby przyjąć, że reprezentuje ona typowe malarstwo ikonowe, z zachowaniem tradycji pisania ikon zawartych w podlinnikach i dawnych traktatach, co wskazywałoby na jej powstanie w końcu XVIII w. W XIX wieku stosowano już opracowania - głównie karnacji - na modłę zachodnią, z bardziej pogłębionym modelunkiem, bez widocznego szrafowania w półcieniach i światłach, a dwiżki i bliki były bardziej wtapiane w kolor otoczenia. 
Rozpoznając organoleptycznie i laboratoryjnie materię ikony oraz sposób jej pisania, ustalono że podobrazie ikony, podobnie jak w warsztacie nowogrodzkim, wykonane jest z drewna olchy, a zastosowany sankir ma barwę zielonkawooliwkową. Nie jest to jednoznaczne ze stwierdzeniem, że ikona powstała w tamtym rejonie, jednak uzyskane wyniki badań z pewnością pomogą w atrybucji i datowaniu podobnych zabytków sztuki.

\section{Wprowadzenie}

W ramach projektu badawczego ASP/WK/19/PB ${ }^{1}$ wykonano konserwację i restaurację ikony $S$ w. Jozafat biskup biełogorodzki (il. 1) ${ }^{2}$. Celem naukowym zadania badawczego jest konserwacja ikony z pełną jej rekonstrukcją oraz przeprowadzenie interdyscyplinarnych badań warsztatu ikonopisarza. Prace poprzedzające zabiegi konserwatorskie obejmowały analizę wszystkich warstw technologicznych ikony.

Konserwacji i restauracji ikon zawsze towarzyszą dylematy, w jakim zakresie uzupełniać warstwy technologiczne dzieła. „Konserwacja jest sztuką kompromisów”3 - jak podkreśla w swoich rozważaniach na temat prac konserwatorsko-rekonstrukcyjnych profesor Władysław Zalewski. W artykule pt.

1 Autorski projekt badawczy pt. „Wiedza o dawnych technikach malarskich w aspekcie zrównoważonego rozwoju”, prowadzony przez dr hab. Danutę Stępień, prof. ASP, w ramach badań statutowych Akademii Sztuk Pięknych w Warszawie, Wydział Konserwacji i Restauracji Dzieł Sztuki.

2 W artykule stosowana jest polska wersja imienia świętego. Jego oryginalne brzmienie to Joasaf (Иoacaф). Ten żyjący i działający w XVIII wieku biskup został ogłoszony świętym przez prawosławną cerkiew w roku 1911. Urodził się w 1705 r. w Pryłukach na Połtawszczyźnie jako Joakim Andrejewicz Horłenko. Należał do wybitnego rodu kozackiego; jego ojciec był pułkownikiem Pułku Pryłuckiego, a matka - córką Danyły Apostoła, który w pewnym okresie był hetmanem kozackim. Joasaf uczył się w Akademii Kijowsko-Mohylańskiej i wstąpił do zakonu, wybrawszy życie mnicha w Monasterze Kijowsko-Brackim. Po wyświęceniu na kapłana prawosławnego został wykładowcą Akademii, a następnie członkiem Kijowskiego Konsystorza Duchownego. Pełnił ważne funkcje: był przeorem Monasteru Spaskiego koło miasta Łubnie na Połtawszczyźnie, następnie stanął na czele Troicko-Sergijewskiej Ławry koło Moskwy, później został biskupem Eparchii Biełgorodzkiej, do której należały ziemie leżącej na pograniczu rosyjsko-ukraińskim tzw. Słobodzkiej Ukrainy, Charkowszczyzna i część Czernihowszczyzny. Późniejszy św. Joasaf odznaczał się wielu cnotami, prowadził życie czynne i świątobliwe, dbał o biednych, lubił czytać, był przyjacielem wybitnego filozofa ukraińskiego Hryhorija Skoworody. Pozostawił w rękopisie prace o tematyce religijnej i zapiski autobiograficzne pt. „Wędrówka po świecie grzesznika Joasafa Horłenki” oraz opublikowane kazania zwane „słowami”. https://grekokatolicy.pl/grekokatolicy/210117/ (dostęp: 21.08.2020).

3 Władysław Zalewski, „Pomiędzy przemalowaniem a preparatem konserwatorskim. Spostrzeżenia dotyczące praktyki konserwatorskiej”, w Sztuka konserwacji. Materiały nadesłane na konferencję z okazji pięćdziesięciolecia Wydziału Konserwacji i Restauracji Dzieł Sztuki ASP w Warszawie 24 i 25 października 1997 r., red. Zofia Jurkowlaniec (Warszawa: Drukarnia W\&P Malbork, 1997), 71-77. 
Pomiędzy przemalowaniem a preparatem konserwatorskim ${ }^{4}$ podaje przykłady, w których szerokie działania rekonstrukcyjne są uzasadnione, oczywiście zawsze z uwzględnieniem autentyzmu malowidła. Konserwacja ikon otwiera szerokie pole do dalszych badań, ponieważ zabiegi o takim charakterze zapoczątkowano dopiero w XX stuleciu ${ }^{5}$. „Do końca XIX wieku stosowano drastyczne metody odnawiania, które z konserwacją nie miały nic wspólnego. [...] Do początku XX wieku ikony nie były uważane za dzieła sztuki. Przełom przyniosło dopiero usunięcie pociemniałej olify z Trójcy Świętej Andrieja Rublowa w 1904 roku"6.

Omawiana w artykule ikona od dawna nie stanowi obiektu kultu; jest piękną pamiątką z podróży jej właścicielki do Petersburga ${ }^{7}$. Opracowanie progra$\mathrm{mu}$ konserwatorskiego zależało od stanu zachowania i przeznaczenia obrazu - w założeniu celem było przywrócenie jego pierwotnego wyglądu, bez pozostawiania „świadków”. Ikona ze św. Jozafatem ma bogatą strukturę, w związku z tym starano się, aby wszystkie elementy, które się na nią składają - technika wykonania, predyspozycje twórcy, kontekst społeczny, a nawet ślady czasu oraz zastosowane narzędzia i materiały - były czytelne. Ponieważ ikonę poddano konserwacji około pięćdziesięciu lat temu, obecnie wszelkie czynności można było podjąć po rozpoznaniu, które warstwy są dodane do oryginału, które zniszczenia są wynikiem czynników atmosferycznych, mechanicznych, a jakie powstały wewnątrz struktury materii malarskiej z upływem czasu.

„Ikona” to nazwa wywodząca się z greckiego słowa eikon - oznaczającego 'obraz święty', 'portret człowieczy’9. Teorii tych obrazów poświęcono wiele publikacji. Na ikonach zwykle widnieją wizerunki Chrystusa, Matki Boskiej, apostołów, ojców Kościoła, archaniołów i świętych; niewiele jest przedsta-

4 Zalewski, „Pomiędzy przemalowaniem a preparatem konserwatorskim”, 74.

5 „Współczesna konserwacja i restauracja ikon to w Polsce zagadnienia stosunkowo młode, sięgające początków lat sześćdziesiątych XX wieku”, Maria Lubryczyńska, „Współczesne metody konserwacji ikon w Polsce w odniesieniu do rozwiązań stosowanych we wschodniej Europie”, Zeszyty Muzeum Warmii i Mazur 6 (zeszyt monograficzny: Ikona. Sacrum i piękno, red. Grażyna Kobrzeniecka-Sikorska) (2010): 99-114.

6 Lubryczyńska, „Współczesne metody konserwacji ikon”, 110.

7 Obraz zakupiony w Desie w Petersburgu w 1974 r., stanowi własność prywatną.

8 „Świadek” jest to pozostawiony przez konserwatora bardzo małych rozmiarów fragment powierzchni zabytku wraz z nawarstwieniami chronologicznie późniejszymi.

9 Zob. „termin ‘eikon' nie znaczył jedynie 'obraz', jak się to przyjmuje w potocznym rozumieniu, lecz w obrębie cywilizacji grecko-rzymskiej oznaczał przede wszystkim 'portret człowieczy” " - cyt. za: Mirosław Piotr Kruk, Ikony XIV-XVI wieku w Muzeum Narodowym w Krakowie. Katalog, t. 1 (Kraków: Muzeum Narodowe w Krakowie, 2019), 11. 
wień biskupów. Na rosyjskich ikonach atrybuty biskupie ${ }^{10}$ stanowią mitra na głowie i przewieszony przez ramiona omoforion ${ }^{11}$ zdobiony krzyżami, trzymany w prawej dłoni krzyż i pastorał w lewej. Świętych - ze świadczącym o świętości nimbem wokół głowy - przedstawiano zarówno w pełnej postaci, jak i w ujęciu półpostaciowym.

\section{Analiza ikony}

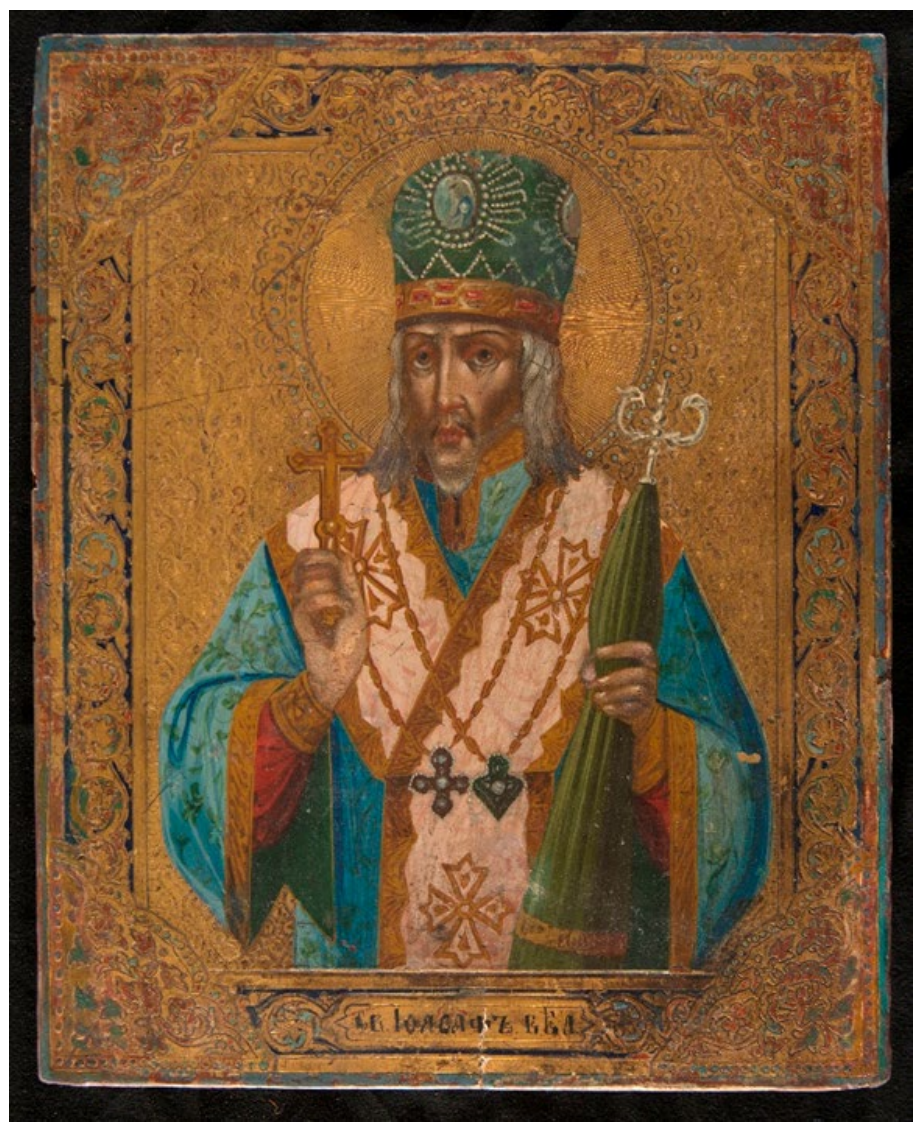

Il. 1. Św. Jozafat biskup biełogorodzki, Rosja, XIX w. Własność prywatna. Lico obrazu w świetle VIS. Fot. R. Stasiuk

10 "Early Bishops", w Andrea Tradigo, Icons and Saints of the Eastern Ortodox Church, trans. Stephen Sartarelli (Los Angeles: The J. Paul Getty Museum, 2006), 302-303.

11 Część biskupiego stroju liturgicznego w Kościele wschodnim (nawiązująca do antycznej tradycji bizantyjskiej). 


\section{1. Dane obiektu}

Rodzaj: ikona.

Temat: Św. Jozafat biskup biełogorodzki (il. 2, 3) ${ }^{12}$.

Autor, warsztat, szkoła: Rosja, XIX w.

Technika: deska, tempera, złocenia.

Pochodzenie: Petersburg, Rosja.

Wymiary: 26,5 x 21,9 x 1,4 cm.

Kształt: prostokąt pionowy.
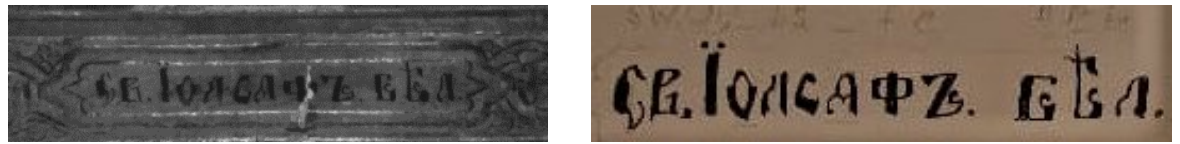

Il. 2, 3. Św. Jozafat biskup biełogorodzki. Inskrypcja pod wizerunkiem biskupa: kaligraficzna rekonstrukcja oraz postać oryginalna (kadr z obrazu). Fot. R. Stasiuk

\section{2. Opis ikonograficzny}

Ikona ukazuje stojącą półpostać św. Jozafata ${ }^{13} \mathrm{z}$ obliczem o śniadej karnacji ${ }^{14}$, w szatach biskupich, z mitrą ${ }^{15}$ na głowie i okalającym je nimbem ${ }^{16}$. Przedstawienie opatrzone jest podpisem umieszczonym wzdłuż dolnej krawędzi obrazu. Święty w prawej dłoni trzyma krzyż, w lewej - pastorał (posoch) owinięty charakterystyczną, wzdłużnie drapowaną tkaniną (sułok). Na powierzchni

12 W wersji rosyjskiej: Іоасаф БЂл(городский). Napis umieszczony na ikonie przetłumaczył ze starosłowiańskiego na język rosyjski Michajlo Skop z Akademii Sztuk Pięknych we Lwowie, krytyk sztuki, założyciel galerii internetowej Ukraińskiego Malarstwa Ikon - Icon.org.ua. Tłumaczenie ułatwiło autorce artykułu zrozumienie inskrypcji. Kaligrafię z rekonstrukcją wykonała Julia Halan, absolwentka Wydziału Konserwacji ASP we Lwowie.

13 Portrety na ikonach mają cechy wspólne: frontalność, uwydatnienie oczu jako symbolu wiecznego życia duchowego, podkreślenie przestrzenności za pomocą lekkiego skrętu szyi w stosunku do popiersia, jasną i żywą kolorystykę.

14 Na ikonach święci mają śniadą karnację, ich oblicza są „koloru ziemi”.

15 Wschodnia mitra ma kształt bulwiastej, całkowicie zamkniętej korony. Wykonuje się ją $\mathrm{z}$ brokatu, adamaszku lub złotej tkaniny. Jest haftowana i zdobiona klejnotami. Na froncie mitry św. Jozafata widać przedstawienie ikony na pionowo ustawionym owalnym polu. Często były to wizerunki Chrystusa, Bogurodzicy, Jana Chrzciciela i krzyża chrześcijańskiego, który biskup całuje przed włożeniem mitry.

16 W stylu zachodnim częściej występuje aureola. Zob. Leonid Uspienski, Teologia ikony, tłum. Maria Żurowska (Poznań: Wydawnictwo Polskiej Prowincji Dominikanów „W drodze”, 1993), 142-143. 
złoconej dzieło jest bardzo bogato ornamentowane, w formie różnorodnych puncowań oraz dekoracji barwnej imitującej emalie. Obrzeża ikony zamyka bordiura i trójkątne naroża ze stylizowanymi liśćmi akantu i innymi elementami florystycznymi (il. 1) ${ }^{17}$.

\section{3. Technika wykonania i stan zachowania ikony}

Ikona napisana jest na podłożu drewnianym w technice temperowej ${ }^{18} \mathrm{z}$ wyraźną znajomością tradycyjnego kanonu. Poziom wykonania grawerunku i puncowann ${ }^{19}$ oraz barwnej ornamentyki na pozłocie dowodzi kunsztu jego twórcy i znajomości tajników sztuki pozłotniczej. Powierzchnia partii karnacji jest gładka, o szlachetnym, aksamitnym (półmatowym) połysku. W miejscach świateł na wypukłych partiach twarzy występują czytelne szrafowania, typowe dla wschodniego malarstwa ikonowego. Szaty i mitra mają powierzchnię matową. Malowane są alla prima, z zastosowaniem farb o barwie mocno rozbielonej.

Stan ikony jest mało stabilny. Ubytki występują we wszystkich warstwach technologicznych obrazu: drewnie, lewkasie, warstwach malarskich i złoceniach (il. 4, 5). Cała powierzchnia jest zabrudzona, pokryta siatką spękań, z widocznymi przetarciami i zadrapaniami. W miejscach karnacji oraz warstwie pozłoty widoczne są stare krakelury -typowe dla drewnianego podobrazia pozostającego pod wpływem wysokiej temperatury. Spod rozległych przemalowań, położonych po formie na partiach szat i mitry, ledwo przebija rysunek starych spękań. Retusze warstwy malarskiej, wykonane niezgodnie z techniką i technologią oryginału (farbą akwarelową), położone są często na ubytkach lewkasu, niekiedy również złoceń, czyli poniżej oryginalnej warstwy malarskiej. Ubytki złocenia, puncowania i imitacji laki również uzupełnione zostały jedynie farbami akwarelowymi. Dotyczy to głównie bordiury i narożników. Na odwrociu widoczne są liczne ślady po żerowaniu ksylofagów. W miejscach większych ubytków drewna zostały założone uzupełnienia w postaci gipsowych kitów.

17 Dekoracja barwna na złocie wykonana jest według dawnej techniki imitacji laki.

18 Danuta Stępień, Tempera żółtkowa jako technika w malarstwie według dawnych przekazów i twórczości wybranych współczesnych artystów (Warszawa: Akademia Sztuk Pięknych, 2010).

19 Puncowanie polega na wyciskaniu wzorów na pozłoconej powierzchni narzędziem zwanym puncą, czyli rodzajem stempla (z rączką) z określonym wzorem opracowanym w metalu. W sprzedaży punce są praktycznie niedostępne. Aby zrekonstruować fragmenty pozłoty na omawianej ikonie, zamówiono kopię punc z występującymi na niej wzorami; pracochłonnego i czasochłonnego wykonania tego misternego narzędzia podjęli się grawer Piotr Kugler oraz jubiler Karol Chodkiewicz. Odciskanie (wybijanie) wzoru puncy wymaga uważności i wyczucia siły przyłożenia ręki lub młoteczka cyzelerskiego na świeżo pozłoconym podłożu, ponieważ jeszcze jest elastyczne, co daje najlepsze efekty (czytelny, graficzny wzór). 
[198]
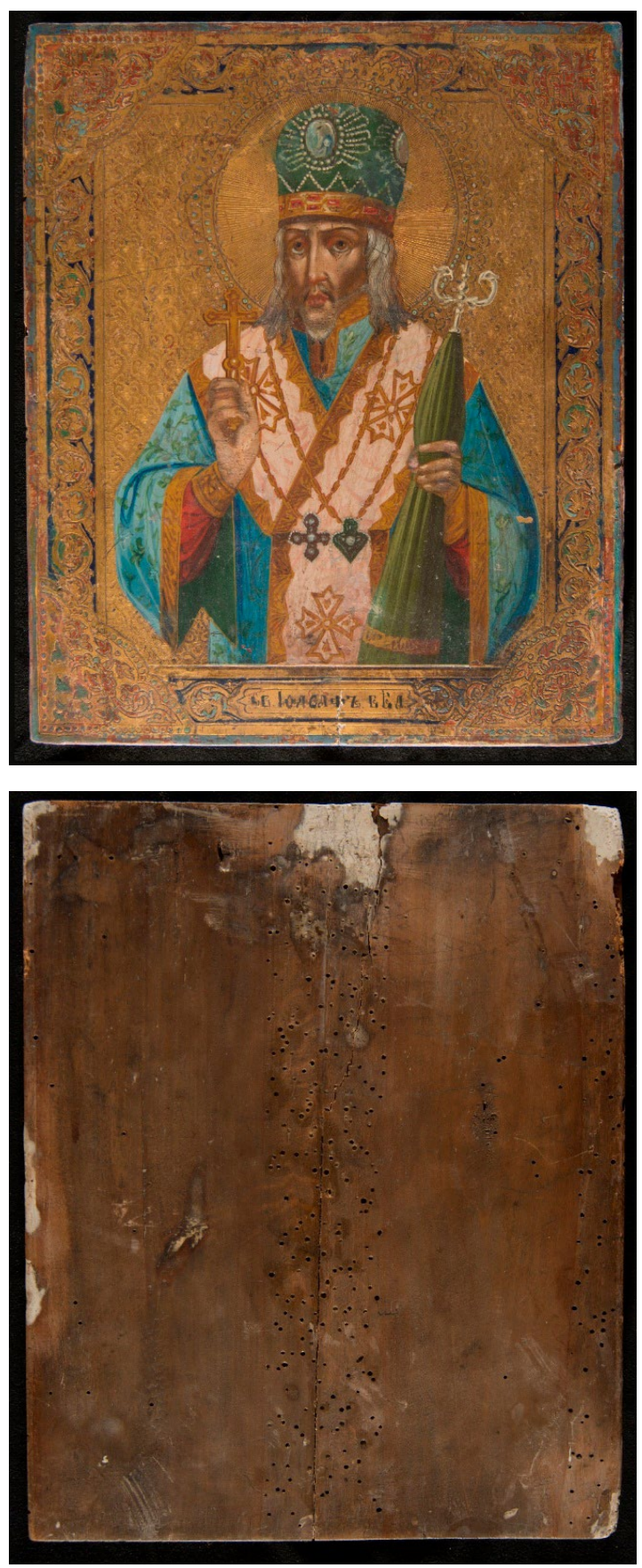

Il. 4, 5. Św. Jozafat biskup biełogorodzki. Lico i odwrocie obrazu w świetle VIS. Fot. R. Stasiuk 

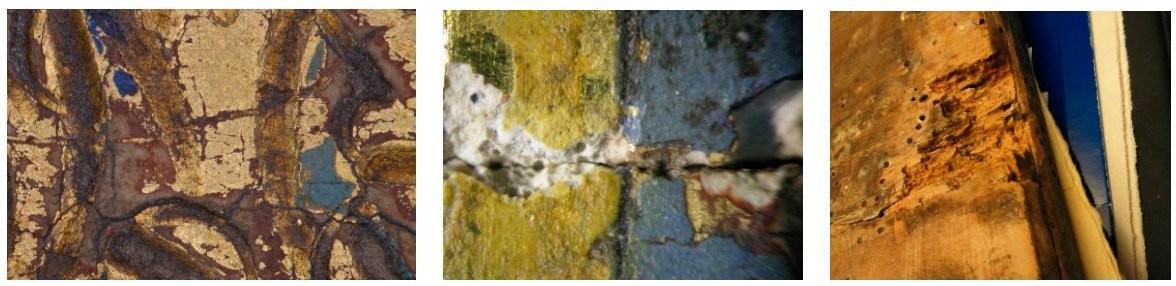

Il. 6-8. Św. Jozafat biskup biełogorodzki. Zdjęcia makroskopowe warstwy malarskiej i odwrocia wykonane mikroskopem Hirox. Fot. w świetle VIS. Stan przed konserwacją. Fot. R. Stasiuk

Na wykonanych fotografiach mikroskopowych widać zakres zniszczeń w złoceniach, puncowaniach i warstwie malarskiej ikony, w postaci przetarć, spękań i zadrapań na jej powierzchni. Zbliżenia odwrocia pokazują liczne otwory wylotowe po żerujących ksylofagach i wykruszenia podobrazia (il. 6-14).
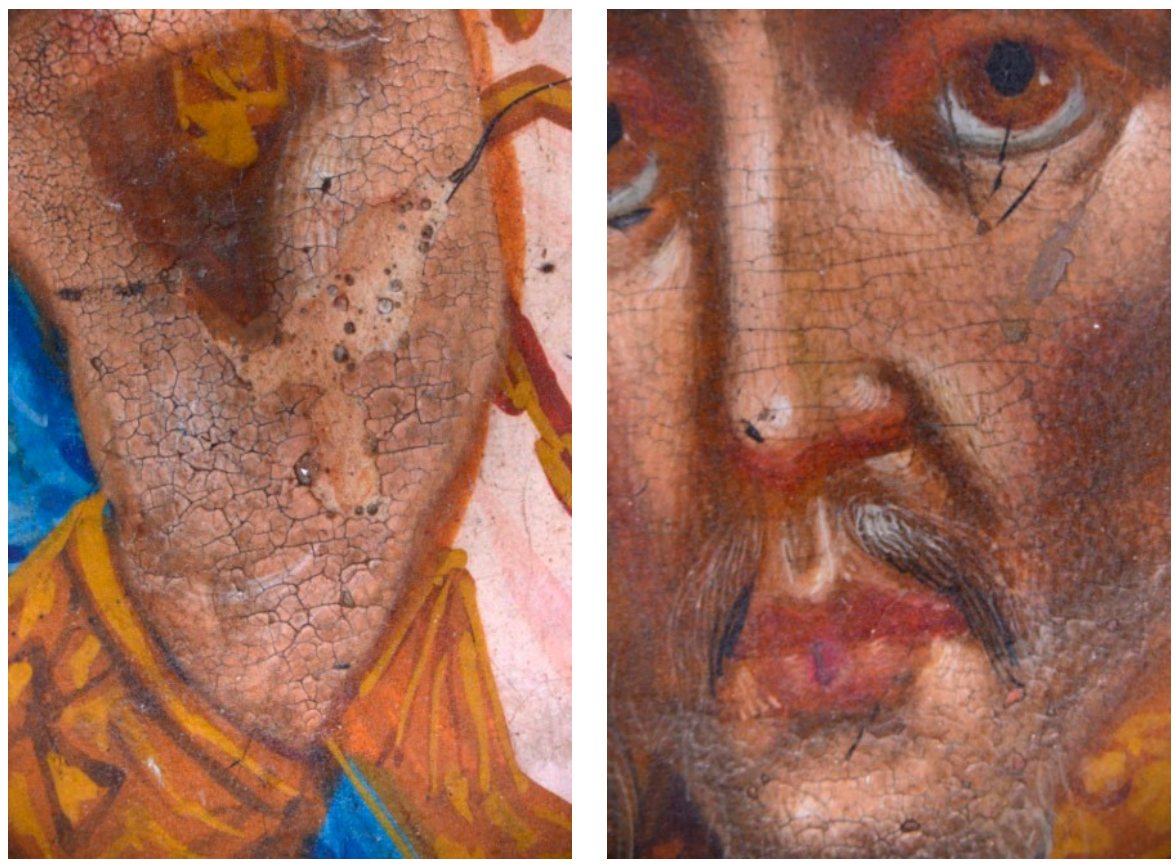

Il. 9, 10. Św. Jozafat biskup biełogorodzki (fragmenty). Warstwa malarska karnacji i szat, stan przed konserwacją. Fot. R. Stasiuk 


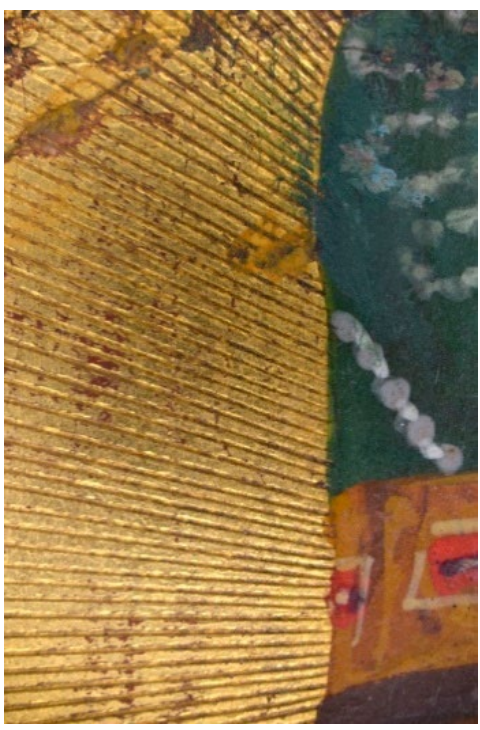

Il. 11. Św. Jozafat biskup biełogorodzki (fragment). Grawerunek aureoli. Fot. R. Stasiuk

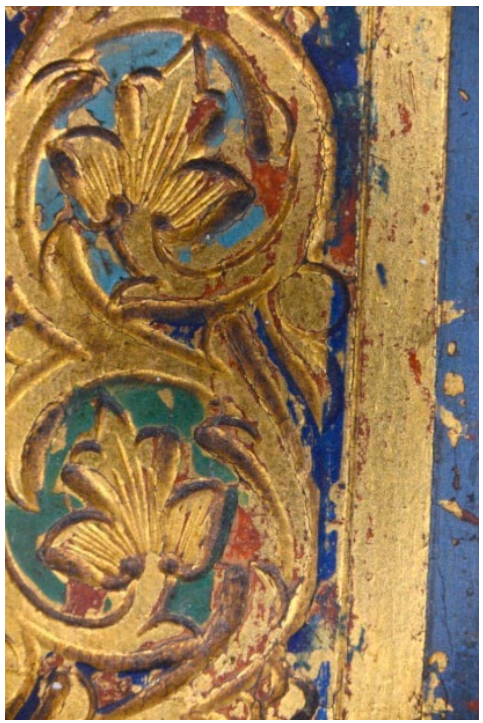

Il. 13. Św. Jozafat biskup biełogorodzki (fragment). Puncowania oraz barwny ornament. Fot. R. Stasiuk

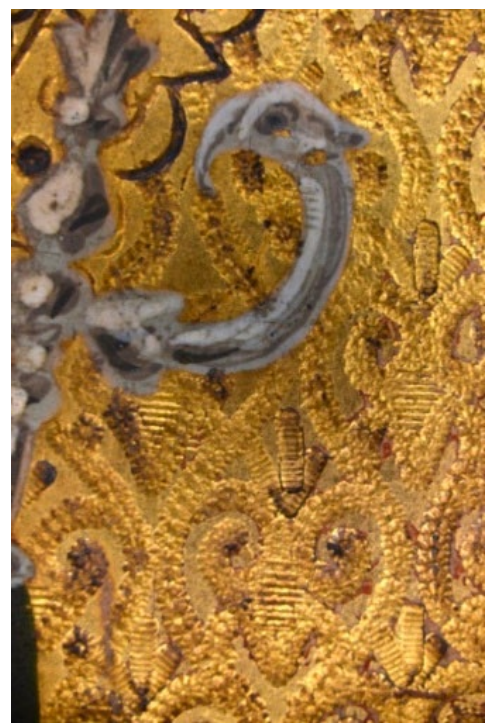

Il. 12. Św. Jozafat biskup biełogorodzki (fragment). Puncowania tła. Fot. R. Stasiuk

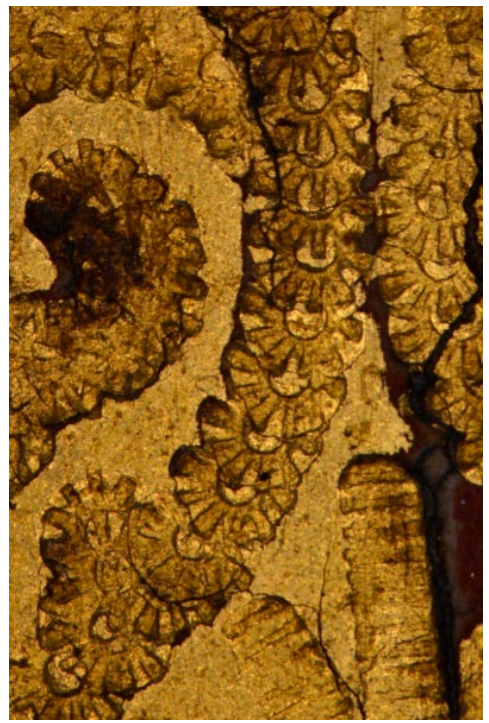

Il. 14. Św. Jozafat biskup biełogorodzki (fragment), Wachlarzowe odbicia głowic punc. Fot. R. Stasiuk 

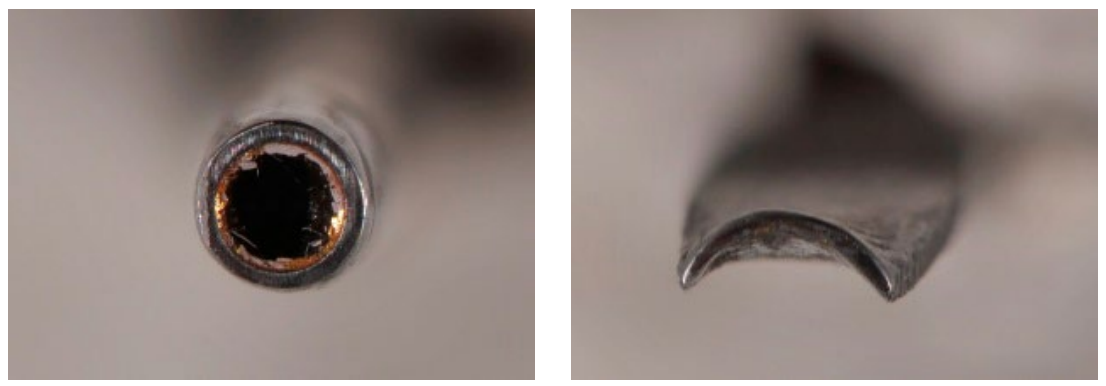

Il. 15, 16. Św. Jozafat biskup biełogorodzki (fragment). Zbliżenie głowic punc. Fot. R. Stasiuk

Opracowanie złoceń i puncowań wskazuje na dużą różnorodność fakturalną powierzchni - liniowe grawerunki, formowanie ornamentów i detali za pomocą kilku punc (il. 15, 16).

\section{Część eksperymentalna - badania fizykochemiczne ${ }^{20}$}

\section{1. Badania nieinwazyjne}

III. 1. 1. Badania VIS, UV, IR, RTG

\section{Metodyka badań}

- Fotografie w świetle rozproszonym (VIS) - wykonano w oświetleniu lamp studyjnych błyskowych firmy Jinbei HD 610 o temperaturze barwowej $6400^{\circ} \mathrm{K}$. Fotografie wykonano aparatem firmy Nikon D 850.

- Fotografie luminescencji wzbudzonej ultrafioletem - wykonano przy użyciu lamp wzbudzających UV firmy Philips TLD zaopatrzonych w filtr Wooda (filtr Wooda absorbuje światło widzialne i przepuszcza tylko światło UV z zakresu 350-390 nm, na który przypada maksimum promieniowania lampy UV), zastosowano filtr Żółty Średni. Fotografie wykonano aparatem firmy Nikon D 850.

- Fotografie w podczerwieni w zakresie 1000-1200 nm (lub reflektografia IR w zakresie 1000-1200 nm) - wykonano w oświetleniu lamp studyjnych bły-

20 Fotografie obrazujące przebieg badań oraz tabele i wykresy wykonali autorzy badań: dr Katarzyna Wantuch-Jarkiewicz, dr Anna Nowicka, dr Elżbieta Jeżewska, mgr Marek Wróbel. 
skowych firmy Jinbei HD 610 o temperaturze barwowej $6400^{\circ} \mathrm{K}$. Fotografie wykonano aparatem firmy Nikon D 800E z konwersją IR.

- Fotografie rentgenowskie RTG - wykonano rentgenem Eresco 42 MF4. Obraz zarejestrowano na kasecie cyfrowej Perkin Elmer Panel. Zakres rejestracji - $28 \mathrm{KV}$ (koniec promieniowania RTG miękkiego - początek promieniowania RTG twardego).

Zbliżenia fragmentów dzieła, zdjęcia dokumentujące luminescencję UV obrazu, zdjęcia w podczerwieni oraz w promieniach rentgenowskich ujawniły poziom zniszczeń warstw powierzchni i struktury obrazu oraz zakres wcześniejszych retuszy (il. 17-19).

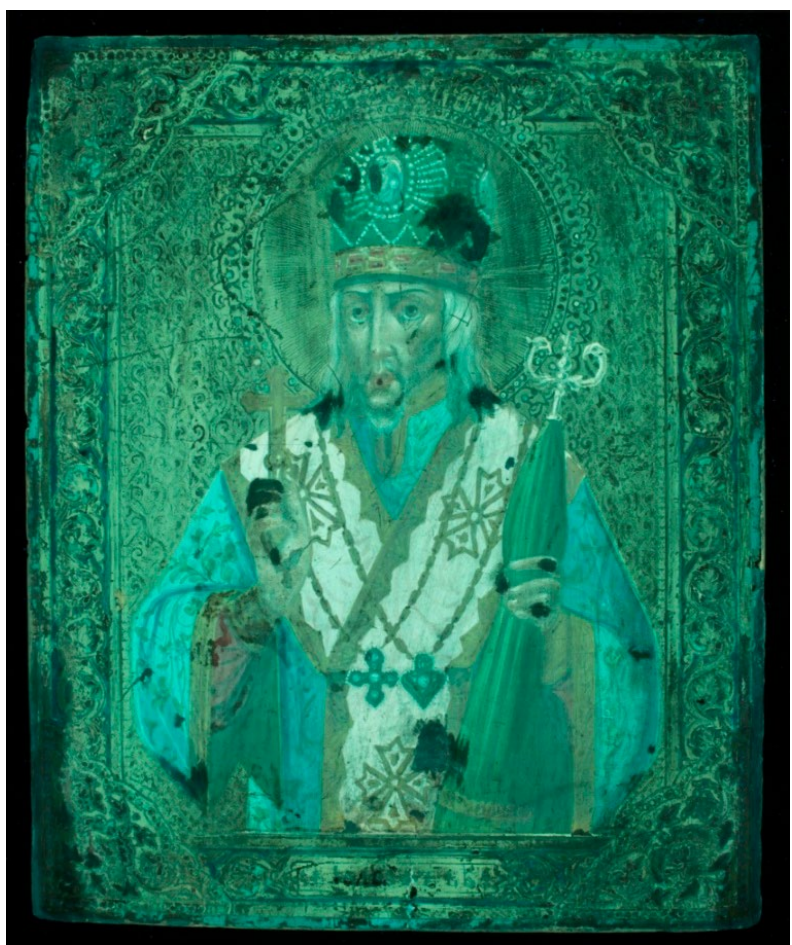

Il. 17. Św. Jozafat biskup biełogorodzki. Lico obrazu, zdjęcie w luminescencji UV. Fot. R. Stasiuk 


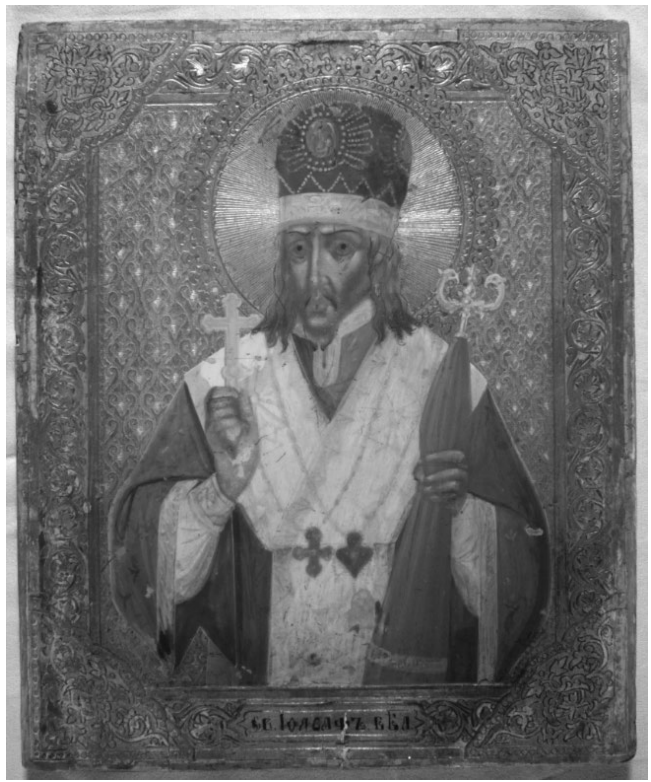

Il. 18. Św. Jozafat biskup biełogorodzki. Zdjęcie w podczerwieni IR. Fot. R. Stasiuk

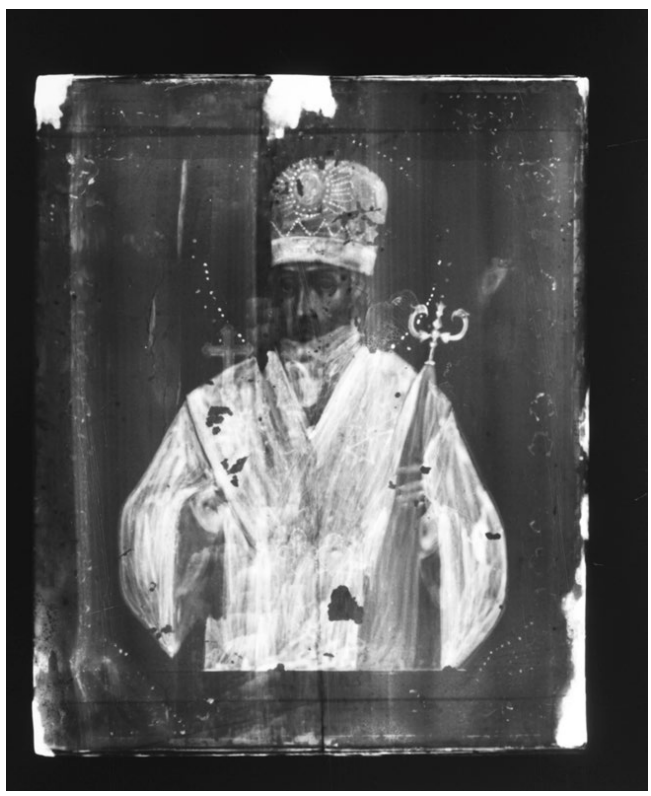

Il. 19. Św. Jozafat biskup biełogorodzki. Rentgenogram. Fot. R. Stasiuk 
Luminescencja UV uwidoczniła wyraźne ślady po żerowaniu ksylofagów i kity gipsowe w drewnianym podobraziu. Zdjęcie ikony w podczerwieni IR pokazało bardzo staranne opracowanie rysunku i ornamentyki, natomiast rentgenogram uczytelnił strukturę drewna, a także łącze dwóch części deski oraz obecność dwóch poprzecznych wstawek wzmacniających (wzdłuż dolnej i górnej krawędzi), których celem było osłabienie skutków pracy drewna. Ponadto rentgenogram uwypuklił malarski modelunek i miejsca, w których występuje biel ołowiowa.

\section{1. 2. Badanie metodą fluorescencji rentgenowskiej (XRF) ${ }^{21}$}

\section{Metodyka badań}

Pomiary (tab. 1) wykonano spektrometrem Genius 7000 XRF firmy Skyray Instrument, z detektorem SDD o rozdzielczości powyżej 139 eV, w którym źródło pobudzenia stanowi lampa rentgenowska srebrowa, operująca w przedziałach napięcia do $40 \mathrm{kV}$ oraz natężenia do $100 \mu \mathrm{A}$. Zakres analityczny obejmuje pierwiastki od magnezu do uranu, w koncentracjach (w zależności od pierwiastka) od 1 do kilkunastu ppm. Czas pomiaru wynosił $120 \mathrm{~s}$, pomiar dzielony na dwa po $60 \mathrm{~s}$, pierwszy dla cięższych pierwiastków, kolejny dla pierwiastków lekkich, obszar pomiarowy odpowiednio $2 \mathrm{~mm}$ oraz $4 \mathrm{~mm}$ średnicy w poszczególnych częściach pomiaru. Widmo raportu z tak wykonanego pomiaru scalone jest w jedno widmo, możliwa jest fotograficzna dokumentacja punktu pomiarowego; obok analizy jakościowej przeprowadzana jest analiza półilościowa. Spektrometr umożliwia wybór ustawień kalibrowanych dla wybranego typu próbek - w przypadku badanej ikony pomiary odbywały się w trybie Pigments, dla którego skalibrowano spektrometr na podstawie próbek warstwy malarskiej wykorzystując ICP2060T.

${ }^{21}$ Analiza składu pierwiastkowego warstw malarskich na podłożu drewnianym przy użyciu przenośnego spektrometru XRF, Warszawa-Wrocław-Toruń, 9 XII 2016 r. - własność intelektualna chroniona prawem. Badania przeprowadzili dr Katarzyna Wantuch-Jarkiewicz i dr hab. Mirosław Wachowiak. 
Tabela 1. Lokalizacja pomiarów wykonanych na ikonie Św. Jozafat biskup biełogorodzki, Rosja, XIX w. (własność prywatna)

\begin{tabular}{|c|l|lc|}
\hline Nr próbki & \multicolumn{1}{|c|}{ Miejsce pobrania } & \multicolumn{1}{|c|}{ Współrzędne } \\
\hline 1 & $\begin{array}{l}\text { Błękit płaszcza } \\
\text { (prawa strona obrazu, nad większym ubytkiem } \\
\text { malatury) }\end{array}$ & $\begin{array}{l}\mathrm{X}: 8,5 \\
\mathrm{~cm}\end{array}$ & $\mathrm{Y}: 18,2$ \\
\hline 2 & $\begin{array}{l}\text { Karnacja - światło karnacji na środkowej, } \\
\text { wypukłej partii nosa }\end{array}$ & $\begin{array}{l}\mathrm{X}: 18 \\
\mathrm{~cm}\end{array}$ & $\mathrm{Y:10,5}$ \\
\hline 3 & $\begin{array}{l}\text { Karnacja twarzy w partii cienia, } \\
\text { z prawej strony przy włosach }\end{array}$ & $\begin{array}{l}\mathrm{X}: 17,7 \\
\mathrm{~cm}\end{array}$ & $\mathrm{Y}: 12,2$ \\
\hline 4 & $\begin{array}{l}\text { Złocenia, tło z prawej strony obrazu, nad } \\
\text { ramieniem postaci }\end{array}$ & $\begin{array}{l}\mathrm{X}: 15 \\
\mathrm{~cm}\end{array}$ & $\mathrm{Y}: 17,7$ \\
\hline
\end{tabular}

\section{Wyniki badań - widma}

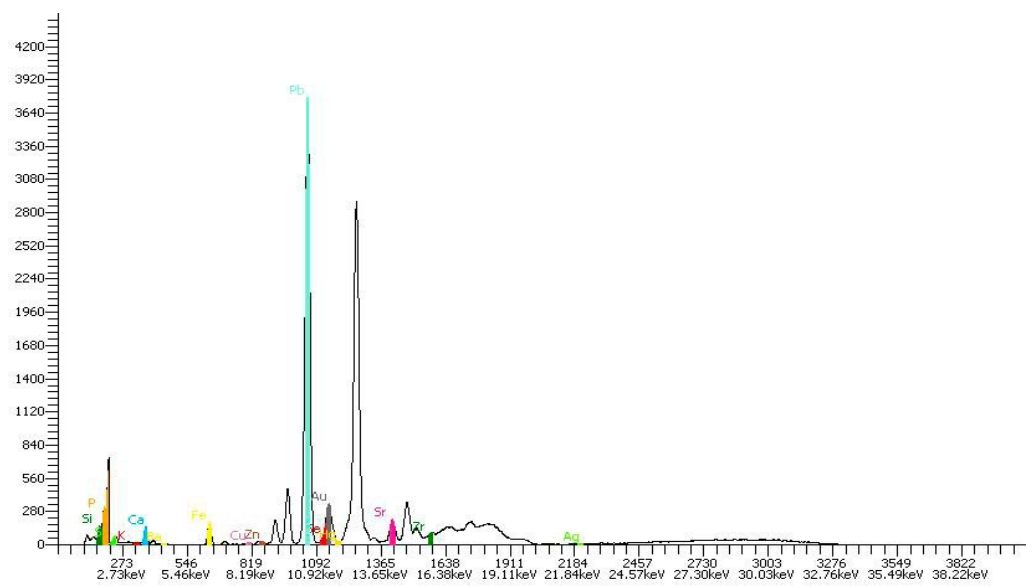

Il. 20. Św. Jozafat biskup biełogorodzki, Rosja, XIX w. Własność prywatna. Próbka nr 1 - błękit: Pb, Ca, P, K, Fe, S, Ba, Sr 
Tabela 2. Wyniki badania składu pierwiastkowego (ilościowa dla pomiaru próbek) warstwy malarskiej ikony Św. Jozafat biskup biełogorodzki metodą rentgenowskiej analizy fluorescencyjnej (Delta Handhelt XRF). Próbka nr 1 - błękit płaszcza

\begin{tabular}{|l|r|}
\hline Element & \multicolumn{1}{|c|}{ Content } \\
\hline $\mathrm{Pb}(\mathrm{ppm})$ & 151412.2820 \\
\hline $\mathrm{Ca}(\mathrm{ppm})$ & 41156.7757 \\
\hline $\mathrm{P}(\mathrm{ppm})$ & 13927.1497 \\
\hline $\mathrm{K}(\mathrm{ppm})$ & 9018.7806 \\
\hline $\mathrm{Fe}(\mathrm{ppm})$ & 4755.3834 \\
\hline $\mathrm{S}(\mathrm{ppm})$ & 840.5836 \\
\hline $\mathrm{Ba}(\mathrm{ppm})$ & 681.1464 \\
\hline $\mathrm{Sr}(\mathrm{ppm})$ & 443.2135 \\
\hline $\mathrm{Cu}(\mathrm{ppm})$ & 344.3149 \\
\hline $\mathrm{Zn}(\mathrm{ppm})$ & 125.1388 \\
\hline $\mathrm{Zr}(\mathrm{ppm})$ & 85.3903 \\
\hline $\mathrm{Au}(\mathrm{ppm})$ & 48.4743 \\
\hline $\mathrm{Ag}(\mathrm{ppm})$ & 29.5715 \\
\hline $\mathrm{Hg}(\mathrm{ppm})$ & 12.7537 \\
\hline $\mathrm{Se}(\mathrm{ppm})$ & 5.2171 \\
\hline $\mathrm{Si}(\%)$ & 0.0723 \\
\hline
\end{tabular}

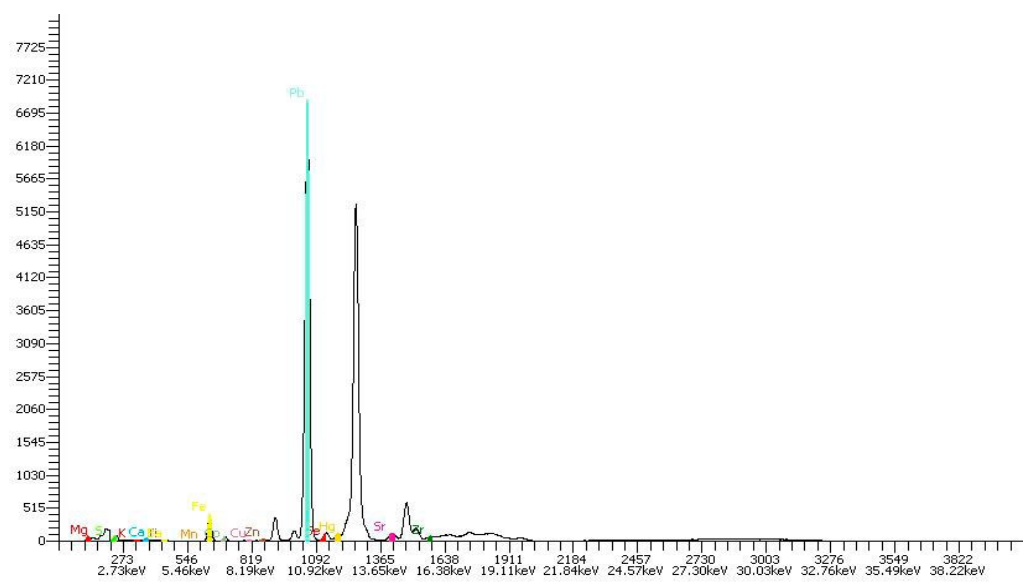

Il. 21. Św. Jozafat biskup biełogorodzki. Próbka nr 2 - karnacja, światło: Pb, Mg, Fe, $\mathrm{Ca}, \mathrm{Hg}$, S. 
Tabela 3. Wyniki badania składu pierwiastkowego (ilościowa dla pomiaru próbek) warstwy malarskiej ikony Św. Jozafat biskup biełogorodzki metodą rentgenowskiej analizy fluorescencyjnej (Delta Handhelt XRF). Próbka nr 2 - karnacja, światło

\begin{tabular}{|l|r|}
\hline Element & \multicolumn{1}{|c|}{ Content } \\
\hline $\mathrm{Pb}(\mathrm{ppm})$ & 276343.0811 \\
\hline $\mathrm{Mg}(\mathrm{ppm})$ & 13192.7101 \\
\hline $\mathrm{Fe}(\mathrm{ppm})$ & 12939.7159 \\
\hline $\mathrm{K}(\mathrm{ppm})$ & 9507.0423 \\
\hline $\mathrm{Ca}(\mathrm{ppm})$ & 7489.0773 \\
\hline $\mathrm{Hg}(\mathrm{ppm})$ & 5884.9145 \\
\hline $\mathrm{S}(\mathrm{ppm})$ & 811.4725 \\
\hline $\mathrm{Sr}(\mathrm{ppm})$ & 258.9253 \\
\hline $\mathrm{Zn}(\mathrm{ppm})$ & 136.3358 \\
\hline $\mathrm{Cu}(\mathrm{ppm})$ & 125.0047 \\
\hline $\mathrm{Ba}(\mathrm{ppm})$ & 47.1712 \\
\hline $\mathrm{Zr}(\mathrm{ppm})$ & 43.8922 \\
\hline $\mathrm{Mn}(\mathrm{ppm})$ & 13.3055 \\
\hline $\mathrm{Ti}(\mathrm{ppm})$ & 8.6904 \\
\hline $\mathrm{Se}(\mathrm{ppm})$ & 4.3560 \\
\hline $\mathrm{Co}(\mathrm{ppm})$ & 0.2312 \\
\hline
\end{tabular}

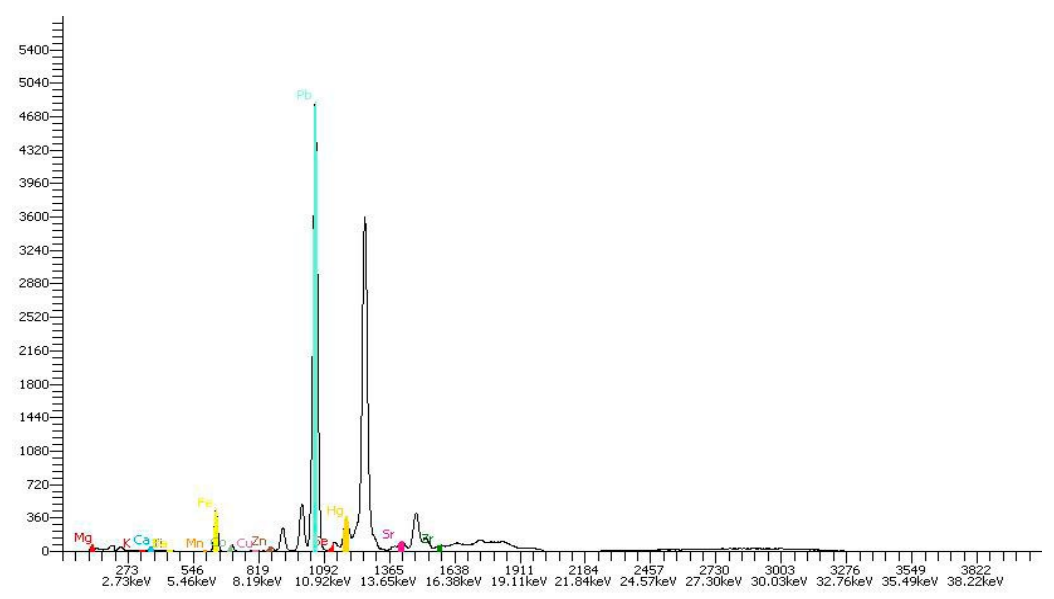

Il. 22. Św. Jozafat biskup biełogorodzki. Próbka nr 3 - karnacja, cień: Pb, Hg, Fe, Ca, Mn 
Tabela 4. Wyniki badania składu pierwiastkowego (ilościowa dla pomiaru próbek) warstwy malarskiej ikony Św. Jozafat biskup biełogorodzki metodą rentgenowskiej analizy fluorescencyjnej (Delta Handhelt XRF). Próbka nr 3 - karnacja, cień

\begin{tabular}{|l|r|}
\hline Element & \multicolumn{1}{|c|}{ Content } \\
\hline $\mathrm{Pb}(\mathrm{ppm})$ & 192393.7537 \\
\hline $\mathrm{Hg}(\mathrm{ppm})$ & 31001.9772 \\
\hline $\mathrm{Fe}(\mathrm{ppm})$ & 13436.9068 \\
\hline $\mathrm{Ca}(\mathrm{ppm})$ & 11052.6305 \\
\hline $\mathrm{Mg}(\mathrm{ppm})$ & 9188.2452 \\
\hline $\mathrm{K}(\mathrm{ppm})$ & 6333.3321 \\
\hline $\mathrm{Ba}(\mathrm{ppm})$ & 374.4408 \\
\hline $\mathrm{Sr}(\mathrm{ppm})$ & 214.8708 \\
\hline $\mathrm{Zn}(\mathrm{ppm})$ & 151.2019 \\
\hline $\mathrm{Mn}(\mathrm{ppm})$ & 84.9066 \\
\hline $\mathrm{Cu}(\mathrm{ppm})$ & 58.2624 \\
\hline $\mathrm{Ti}(\mathrm{ppm})$ & 35.5577 \\
\hline $\mathrm{Zr}(\mathrm{ppm})$ & 29.7451 \\
\hline $\mathrm{Se}(\mathrm{ppm})$ & 3.1359 \\
\hline $\mathrm{Co}(\mathrm{ppm})$ & 0.2007 \\
\hline
\end{tabular}

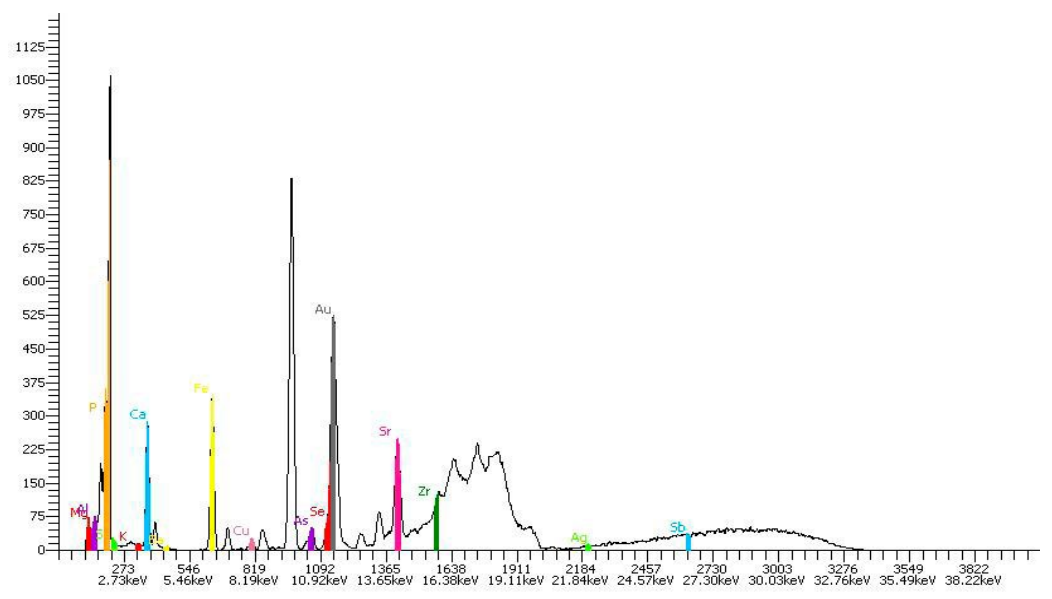

Il. 23. Św. Jozafat biskup biełogorodzki. Próbka nr 4 - złocenia: Au, Ag, Ca, Al, Mg, P, $\mathrm{Fe}, \mathrm{K}, \mathrm{Cu}$ 
Tabela 5. Wyniki badania składu pierwiastkowego (ilościowa dla pomiaru próbek) warstwy malarskiej ikony Św. Jozafat biskup biełogorodzki metodą rentgenowskiej analizy fluorescencyjnej (Delta Handhelt XRF). Próbka nr 4 - złocenia

\begin{tabular}{|l|c|}
\hline \multicolumn{1}{|c|}{ Element } & Content \\
\hline $\mathrm{Ca}(\mathrm{ppm})$ & 80373.1156 \\
\hline $\mathrm{Mg}(\mathrm{ppm})$ & 14053.4794 \\
\hline $\mathrm{P}(\mathrm{ppm})$ & 10621.0380 \\
\hline $\mathrm{Fe}(\mathrm{ppm})$ & 9906.6482 \\
\hline $\mathrm{K}(\mathrm{ppm})$ & 6272.3017 \\
\hline $\mathrm{Cu}(\mathrm{ppm})$ & 523.0246 \\
\hline $\mathrm{Sr}(\mathrm{ppm})$ & 522.6918 \\
\hline $\mathrm{S}(\mathrm{ppm})$ & 345.3797 \\
\hline $\mathrm{As}(\mathrm{ppm})$ & 153.9471 \\
\hline $\mathrm{Zr}(\mathrm{ppm})$ & 109.4041 \\
\hline $\mathrm{Au}(\mathrm{ppm})$ & 78.1883 \\
\hline $\mathrm{Ba}(\mathrm{ppm})$ & 60.3499 \\
\hline $\mathrm{Ag}(\mathrm{ppm})$ & 57.0223 \\
\hline $\mathrm{Se}(\mathrm{ppm})$ & 3.8515 \\
\hline $\mathrm{Sb}(\mathrm{ppm})$ & 2.3784 \\
\hline $\mathrm{Al}(\%)$ & 0.5415 \\
\hline
\end{tabular}

Na błękit (próbka nr 1; il. 20, tab. 2) składa się biel ołowiowa, niewykluczony błękit organiczny (Ca, P, K), ewentualnie pruski (Fe, K, P). Bar z bieli barytowej wskazuje na dziewiętnastowieczne lub późniejsze przemalowania. Niewielka ilość krzemu (Si) nie wyklucza małych domieszek ultramaryny. W światłach karnacji (próbka nr 2; il. 21, tab. 3) można rozpoznać biel ołowiową, ziemne pigmenty żelazowe i cynober, natomiast w jej cieniach (próbka nr 3; il. 22, tab. 4) biel ołowiową z cynobrem, ugrem i innymi pigmentami ziemnymi - prawdopodobnie umbrą. Na złocenia i jego podłoże (próbka nr 4; il. 23, tab. 5) składa się stop złota i srebra, wapń z zaprawy, glin oraz żelazo najprawdopodobniej z bolusu (czerwona glinka - m.in. glinokrzemiany, krzemiany, żelazo, tytan) jako podkład pod złocenia. 


\section{Wniosek}

Badania wykazały, że ikona napisana została na gruncie przygotowanym na bazie związku wapnia - najprawdopodobniej kredy lub gipsu. Złocenia wykonano płatkami srebrno-złotymi na czerwonym bolusie. Karnację namalowano bielą ołowiową z dodatkiem bieli barytowej(?) i przy wykorzystaniu czerwieni żelazowej, ugrów, umbry i cynobru. Do namalowania błękitów użyto ultramaryny, błękitu organicznego(?), ewentualnie błękitu pruskiego.

\section{2. Badania inwazyjne - metodyka i wyniki}

Celem badań była identyfikacja podłoża malarskiego (drewna) oraz wypełniaczy zaprawy i pigmentów, a także rozpoznanie budowy stratygraficznej ikony ${ }^{22}$.

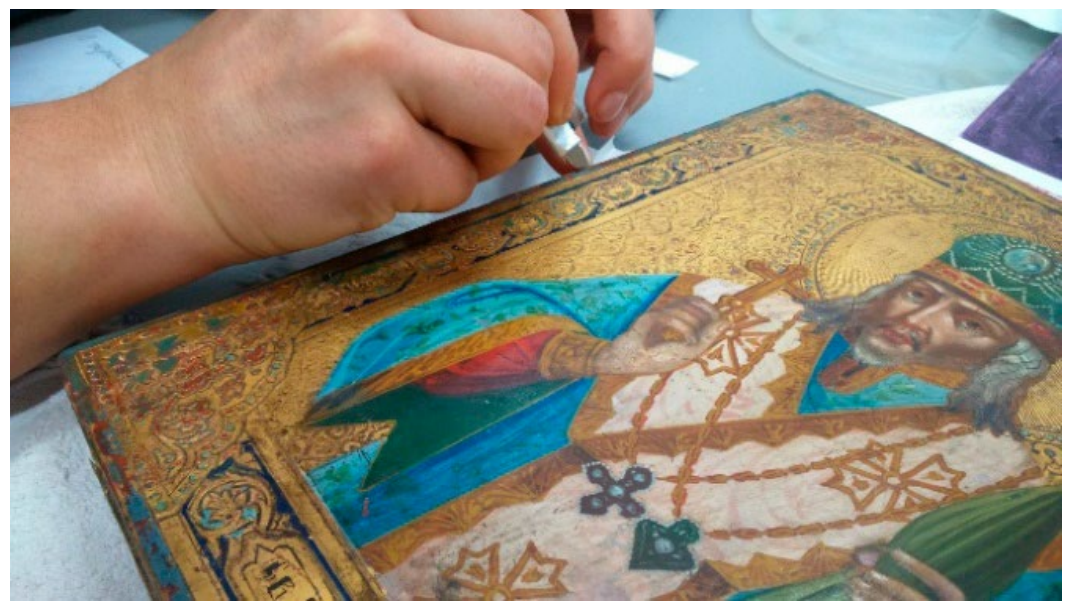

Il. 24. Św. Jozafat biskup biełogorodzki. Pobieranie próbek pigmentów do testów

Wykaz próbek pobranych z ikony Św. Jozafat biskup biełogorodzki z określeniem miejsca ich pobrania i przeznaczenia (il. 24):

- próbka nr 1: zaprawa - biała - środkowa część górnej krawędzi [x=11; $\mathrm{y}=26,5]$;

22 Badania wykonane w Katedrze Badań Specjalistycznych i Technik Dokumentacyjnych na Wydziale Konserwacji i Restauracji Dzieł Sztuki Akademii Sztuk Pięknych w Warszawie. Badania przeprowadzili dr Anna Nowicka, dr Elżbieta Jeżewska, mgr Marek Wróbel. 
- próbka nr 2: do badania stratygrafii - niebieska warstwa malarska środek dolnej krawędzi, miejsce licznych wykruszeń wzdłuż pionowego pęknięcia deski $[\mathrm{x}=11,7 ; \mathrm{y}=0,0]$;

- próbka nr 3: zielona warstwa malarska - oznaczenie pigmentów - górna część nakrycia głowy [x=11,2; $\mathrm{y}=23,2]$;

- próbka nr 4: czerwona warstwa malarska - oznaczenie pigmentów prawy rękaw spodniej szaty $[\mathrm{x}=6 ; \mathrm{y}=7,8]$;

- próbka nr 5: drewno - odwrocie.

\section{2.1. Identyfikacja drewna - próbka nr 5}

Powierzchnię przekroju poprzecznego próbki wyrównano skalpelem i oglądano pod mikroskopem stereoskopowym (Prolab MSZ). Następnie ścięto cienkie skrawki z przekrojów stycznego i promieniowego, z których przygotowano preparaty wodne przeznaczone do oglądu w świetle przechodzącym (mikroskop biologiczny Nikon E200).

Wygląd makroskopowy. Drewno jest lekkie, miękkie, o różowawym kolorze; są w nim widoczne liczne chodniki larwalne z mączką drzewną i odchodami.

Wygląd mikroskopowy. Na przekroju poprzecznym jest widoczna struktura drewna liściastego. Na przekroju stycznym promienie łykodrzewne są jednoszeregowe, bardzo wysokie (10-25 komórek); część promieni łykodrzewnych sytuuje się bardzo blisko siebie, oddziela je jedna komórka innej tkanki. Stwierdzono obecność promieni pozornie szerokich. Przekrój promieniowy ujawnia drabinkową perforację poprzecznych ścian naczyń. Ściany podłużne są gładkie, bez zgrubień spiralnych. Promienie łykodrzewne są jednorodne.

\section{2.2. Identyfikacja wypełniaczy zaprawy i pigmentów - próbki nr 1, 3, 4}

Identyfikacji wypełniaczy zaprawy i pigmentów z warstw malarskich dokonano na podstawie: obserwacji mikroskopowej w świetle odbitym przy użyciu mikroskopu stereoskopowego Prolab MSZ (maks. pow. 45x) oraz rozmazów wodnych i w 4M NaOH w świetle przechodzącym przy użyciu mikroskopu biologicznego Nikon Eclipse 50i (maks. pow. 400x); zachowania w kwasach (3M $\mathrm{HCl}$ i st. $\mathrm{HNO}_{3}$ ) oraz w zasadzie sodowej (4M NaOH); reakcji mikrokrystalicznych i kroplowych potwierdzających obecność wybranych jonów nieorganicznych; analizy składu pierwiastkowego przy użyciu skaningowego mikroskopu elektronowego JEOL JSM-6380LA sprzężonego z mikrosondą elektronową EDS. 
III. 2.2.1. Zaprawa - próbka nr 1 (il. 25, 26)

Wygląd mikroskopowy $w$ świetle odbitym. Warstwa białej zaprawy ma odcień lekko żółtawy, jest porowata, krucha. Wygląd mikroskopowy w świetle przechodzącym (rozmaz wodny) (pow. $x$ 400). Zaobserwowano przezroczyste bezbarwne ziarna, drobne i bardzo drobne, oraz liczne duże, półprzejrzyste ziarna podłużne.

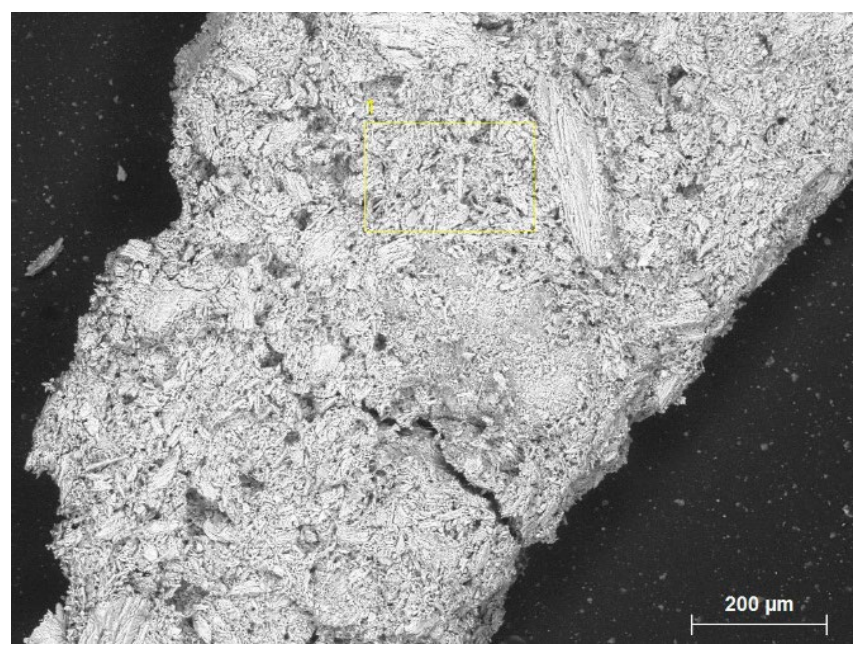

Il. 25. Św. Jozafat biskup biełogorodzki. Próbka nr 1. Obraz SEM w świetle elektronów odbitych. Widoczne skupiska podłużnych kryształów gipsu

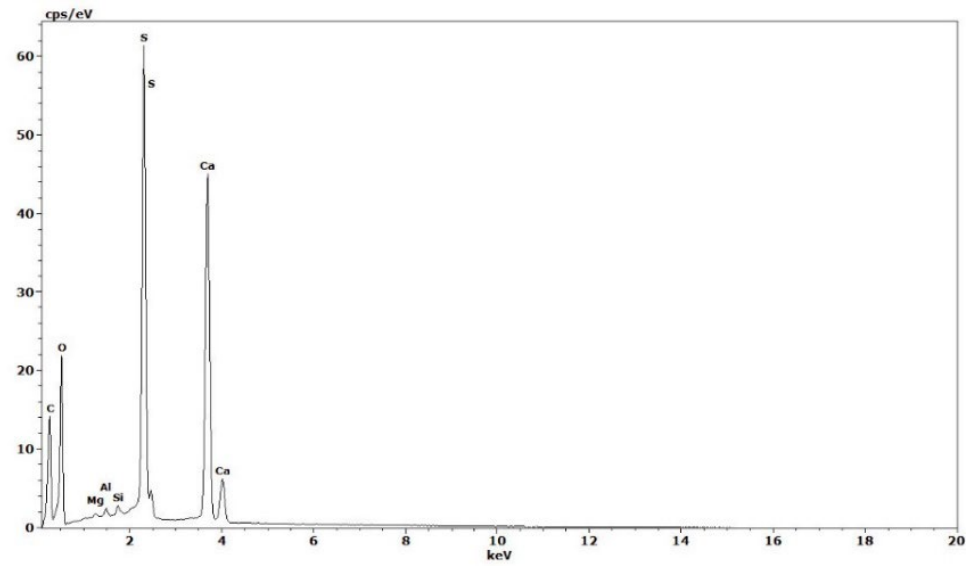

Il. 26. Św. Jozafat biskup biełogorodzki. Próbka nr 1. Analiza SEM-EDS nr 1 
Rozpuszczalność $\boldsymbol{w}$ kwasach $\boldsymbol{i}$ zasadach. 3M HCl - wypełniacz nie roztwarza się, nie widać wydzielania gazu. Analiza SEM-EDS ${ }^{23}$. Wykazano obecność S, Ca, O, C, Al, Mg, Si ${ }^{22}$.

Reakcje mikrochemiczne. Reakcja rekrystalizacji gipsu: wynik pozytywny. Wykonano rekrystalizację tego związku - do próbki dodano kroplę $3 \mathrm{M} \mathrm{HCl}$ i lekko ogrzano, na brzegach kropli powstały charakterystyczne igły i pęczki igieł $\mathrm{CaSO}_{4} \cdot 2 \mathrm{H}_{2} \mathrm{O}$.

III. 2.2.2. Czerwień - próbka nr 3 (il. 27-29)

Wygląd mikroskopowy $w$ świetle odbitym. Warstwa ma kolor intensywnie czerwony.

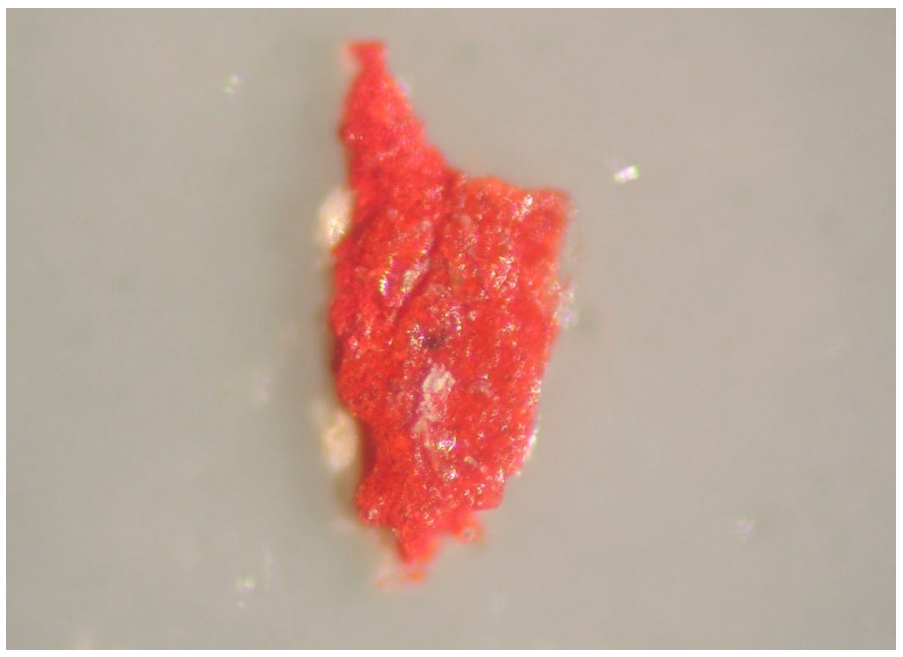

Il. 27. Św. Jozafat biskup biełogorodzki. Próbka nr 3. Wygląd próbki w świetle odbitym. Zdjęcie poglądowe do analizy SEM-EDS

Wygląd mikroskopowy w świetle przechodzącym (rozmaz wodny) (pow. $\mathrm{x}$ 1000). Zaobserwowano liczne skupiska ciemnoczerwone oraz ziarna jasnoczerwone, zaokrąglone, przejrzyste. Wygląd ziaren zaokrąglonych wskazuje na czerwień organiczną.

${ }^{23}$ Wytłuszczoną czcionką zaznaczono pierwiastki występujące w ilości dominującej. Pierwiastki uszeregowano według wysokości pików, zaczynając od tego, który daje najsilniejszy pik. 


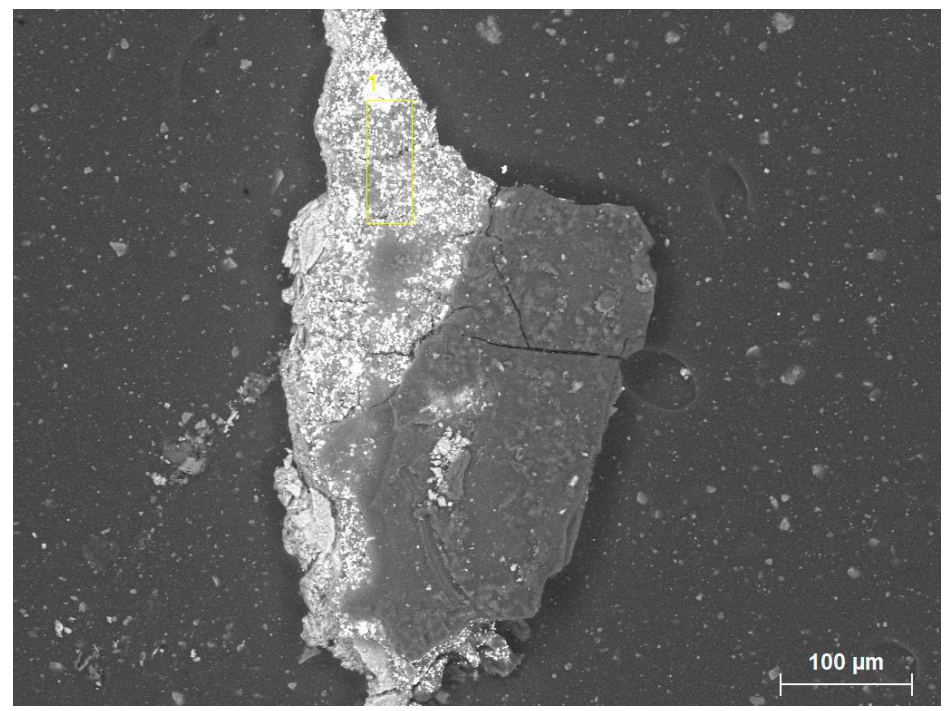

Il. 28. Św. Jozafat biskup biełogorodzki. Próbka nr 3. Obraz SEM w świetle elektronów odbitych

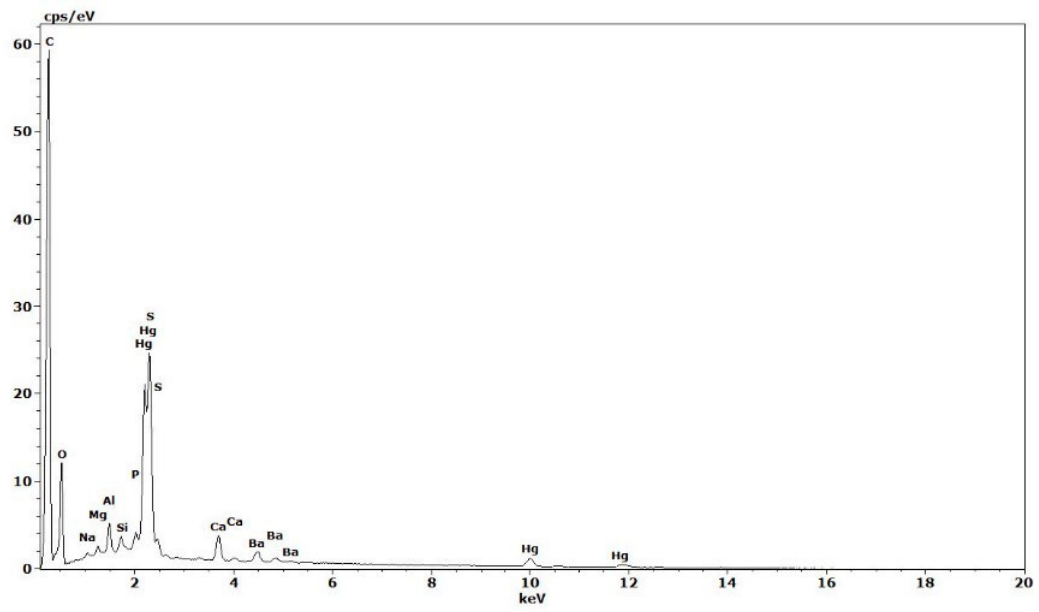

Il. 29. Św. Jozafat biskup biełogorodzki. Próbka nr 3. Analiza SEM-EDS nr 1

Rozpuszczalność $\boldsymbol{w}$ kwasach $\boldsymbol{i}$ zasadach. 3M HCl - czerwień nie ulega zmianie; stęż. $\mathrm{HNO}_{3}$ - jw.; $4 \mathrm{M} \mathrm{NaOH}$ - pigmenty nie rozpuszczają się; część ziaren zmienia barwę na różowo-fioletową. Analiza SEM-EDS. Wykazano obecność C, S, Hg, O, Ca, Ba, Al, Mg, Si, P. 
III. 2.2.3. Zieleń - próbka nr 4 (il. 30-33)

Wygląd mikroskopowy w świetle odbitym. Warstwa zielona jest jednorodna, bez skupisk o innym kolorze lub odcieniu.

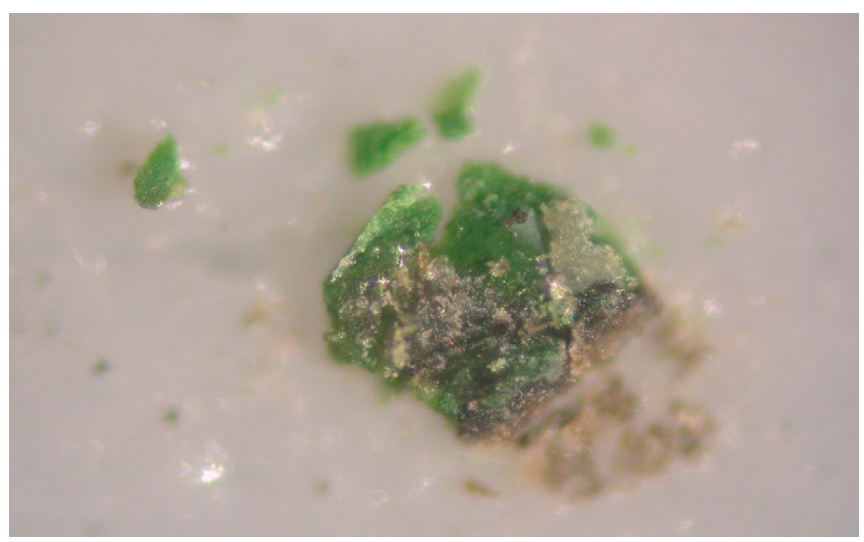

Il. 30. Św. Jozafat biskup biełogorodzki. Próbka nr 4. Fotografia mikroskopowa próbki w świetle odbitym. Zdjęcie poglądowe do analizy SEM-EDS

Wygląd mikroskopowy $\boldsymbol{w}$ świetle przechodzq̨cym (rozmaz wodny) (pow. $\mathrm{x} 400$ ). Zaobserwowano liczne skupiska zielonych ziaren, nierównomiernie zabarwionych, oraz dodatek ziaren niebieskich i żółtych. Widoczne są także duże ziarna bezbarwne, do których przylegają ziarna pigmentu o zielonej barwie.

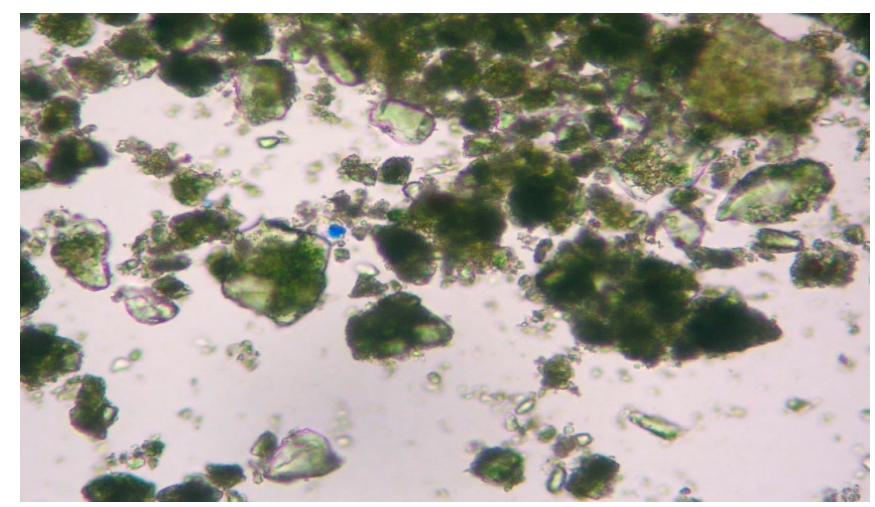

Il. 31. Św. Jozafat biskup biełogorodzki. Próbka nr 4. Rozmaz wodny w świetle przechodzącym (pow. x 400). Widoczne ziarna błękitu pruskiego 


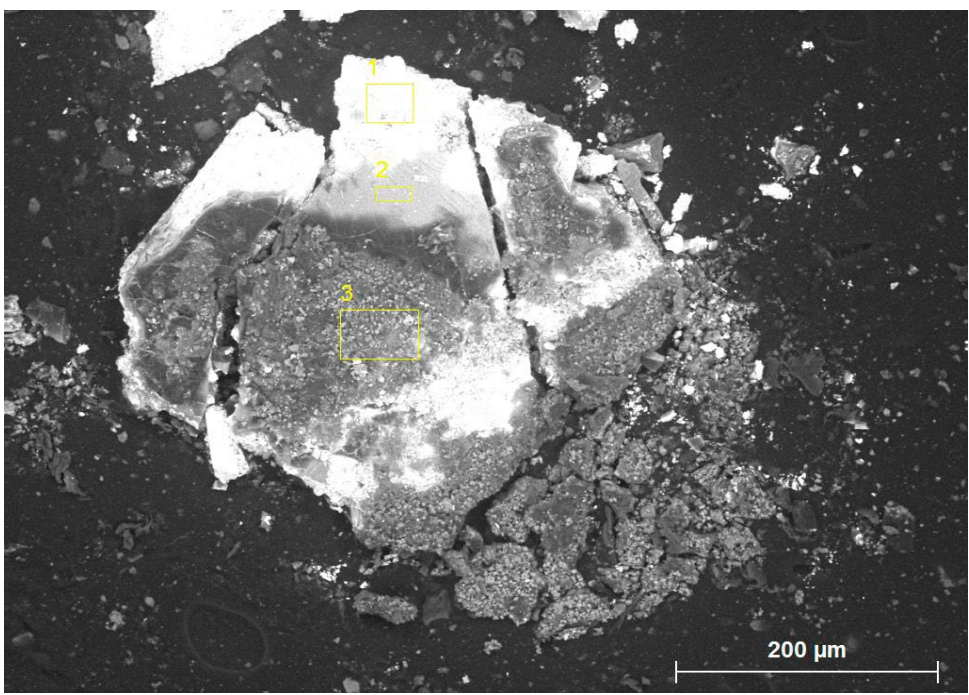

Il. 32. Św. Jozafat biskup biełogorodzki. Próbka nr 4. Obraz SEM w świetle elektronów odbitych

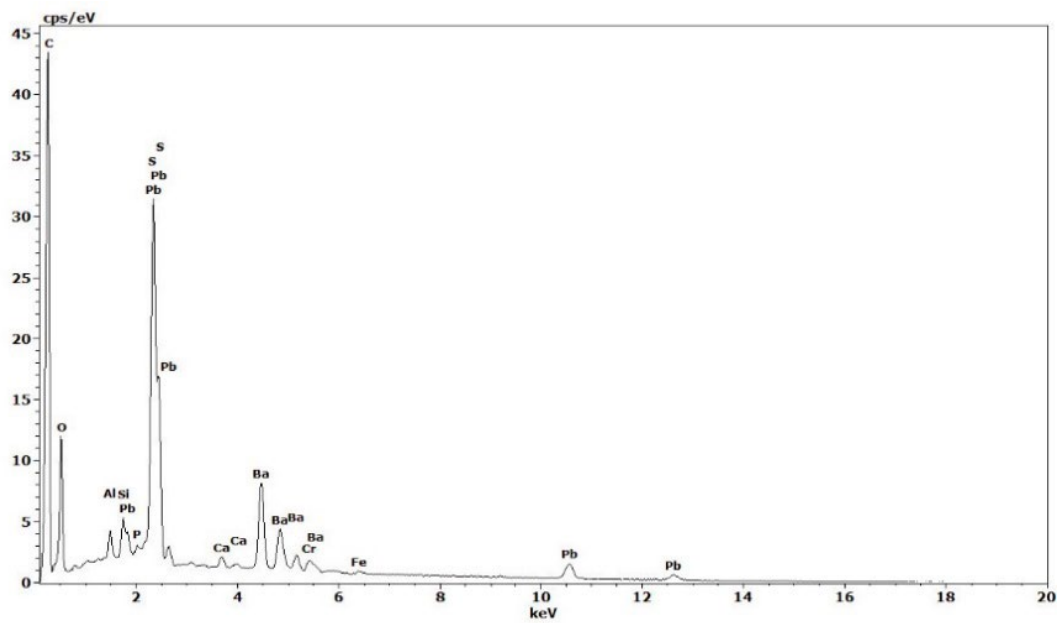

Il. 33. Św. Jozafat biskup biełogorodzki. Próbka nr 4. Analiza SEM-EDS (warstwa zielona)

Rozpuszczalność $\boldsymbol{w}$ kwasach i zasadach. Stężenie $\mathrm{HNO}_{3}$ - warstwa zmienia kolor na niebieski; stężenie $4 \mathrm{M} \mathrm{NaOH}$ - warstwa zmienia kolor na żółty. Analiza SEM-EDS nr 1. Wykazano obecność C, Pb, S, O, Ba, Si, Al, Ca, Cr, Fe, P. 


\section{III.2.3. Stratygrafia - próbka nr 2 (il. 34, tab. 6)}

Próbkę przeznaczoną do rozpoznania stratygrafii zatopiono w żywicy modyfikowanej Premacryl Plus. Następnie bok utwardzonej kostki żywicy, do którego bezpośrednio przylegała próbka, wyszlifowano papierami ściernymi o coraz mniejszej gradacji. Tak przygotowaną próbkę oglądano w kropli wody za pomocą mikroskopu stereoskopowego Nikon SMZ 1000. Fotografie mikroskopowe przekrojów stratygraficznych wykonano używając aparatu cyfrowego Nikon Coolpix 8400 połączonego z wymienionym wyżej mikroskopem.

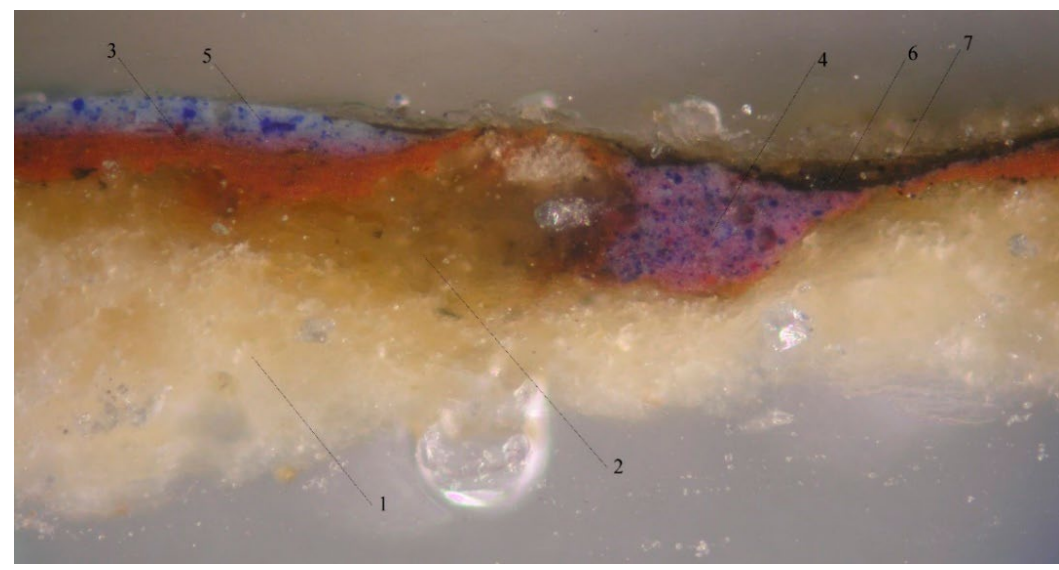

Il. 34. Św. Jozafat biskup biełogorodzki. Przekrój stratygraficzny próbki 2. Pow. x 200. Widoczna warstwa jasnej zaprawy, warstwa czerwona, fioletowa, błękitna, czarna i żółtawa

Tabela 6. Oznaczenie warstw przekroju stratygraficznego próbki nr 2 pobranej z ikony Św. Jozafat biskup biełogorodzki.

\begin{tabular}{|c|l|l|}
\hline $\begin{array}{c}\text { Oznaczenie } \\
\text { warstwy }\end{array}$ & \multicolumn{1}{|c|}{ Rodzaj i kolor warstwy } & \multicolumn{1}{|c|}{$\begin{array}{c}\text { Grubość } \\
\text { warstwy [mm] }\end{array}$} \\
\hline 1 & Warstwa zaprawy w kolorze kremowym & $0,23 \mathrm{~mm}$ \\
\hline 2 & $\begin{array}{l}\text { Warstwa zaprawy w kolorze żółtym (przypuszczalnie jest to } \\
\text { kontynuacja warstwy nr 1, a silna różnica kolorystyczna wynika } \\
\text { z wtórnego przesączenia zaprawy spoiwem z górnych warstw) }\end{array}$ & \\
\hline 3 & Warstwa ceglastoczerwona & $0,005+0,015$ \\
\hline 4 & Warstwa fioletowa (mieszanina bieli, czerwieni i błękitu) & $\begin{array}{l}0,005+0,007 \\
\text { (maks. 0,06) }\end{array}$ \\
\hline 5 & Warstwa błękitna (mieszanina bieli i błękitu) & 0,015 \\
\hline 6 & Warstwa czarna, bardzo cienka & 0 k. 0,002 \\
\hline 7 & Warstwa przejrzysta, żółtawa (werniks) & 0,007 \\
\hline
\end{tabular}




\section{III.2.4. Wniosek}

Podłoże wykonano z drewna olchy ( $s p$. Alnus). Wypełniaczem zaprawy jest gips. Warstwa malarska czerwona zawiera cynober, przypuszczalnie otrzymany sztucznie, oraz czerwień organiczną. Warstwa malarska zielona zawiera zieleń chromianową (mieszaninę błękitu pruskiego i żółcieni chromianowej - chromianu ołowiu) z dodatkiem białego pigmentu, przypuszczalnie bieli barytowej (wskazuje na to kształt i wielkość ziaren).

\section{Przebieg konserwacji z rekonstrukcją pozłoty i puncowań}

Wstępne prace przy ikonie polegały na jej oczyszczeniu. Wcześniejsze ingerencje „restauratorskie” ${ }^{24}$ stały się bezpośrednią przyczyną stopniowej destrukcji obiektu. Zaniechano wówczas dezynsekcji drewna przed nałożeniem kitów (w dodatku niezgodnych z materią drewna, bo gipsowych) i jego utwardzenia, co skutkowało dalszym żerowaniem ksylofagów, budujących w podobraziu misterną strukturę kanałów oddzielonych cienkimi ściankami.

Celem zachowania zabytkowej materii podłoża, po usunięciu gipsowych „stempli” drewniane podobrazie poddano dezynsekcji ${ }^{25}$; zabiegi owadobójcze powtarzano wielokrotnie, ponieważ owady wykazywały znaczną aktywność. Długo można było obserwować osypujące się z otworów wylotowych trociny. Następnie wzmocniono osłabioną strukturę podobrazia za pomocą środka konsolidującego. Do dezynsekcji zastosowano Permethrin 25/75 - Komplet firmy Kremer (nr katalogowy 78715), natomiast do utwardzenia osłabionej struktury drewna użyto Konsolidatora firmy Kremer (nr katalogowy 67401). Kolejny etap polegał na usunięciu przemalowań - przy czym, chcąc ograniczyć ingerencje w materię zabytku, postanowiono nie usuwać rozległych przemalowań położonych po formie ${ }^{26}$ szat i mitry - a następnie uzupełnieniu warstw zaprawy, złoceń i warstwy malarskiej. Na końcu zrekonstruowano puncowania oraz barwną dekorację na pozłocie.

24 Prace „konserwatorsko-restauratorskie” zostały przeprowadzone w Sandomierzu po 1976 r. Brak danych o wykonawcy i dokumentacji konserwatorskiej.

25 Drewno olchy jest podatne na żerowanie szkodników, a niekiedy ksylofagi potrafią przetrwać w komorze fumigacyjnej nawet po dezynsekcji.

${ }^{26}$ Rysunek widoczny na fotografii w podczerwieni i rtg pokrywa się z rysunkiem szat i mitry widocznym na ikonie. 


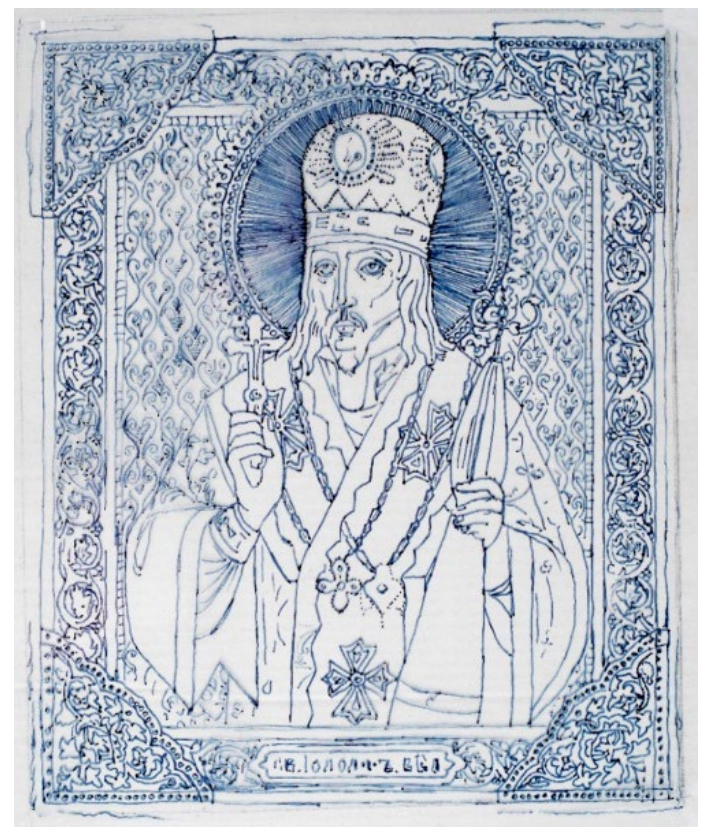

Il. 35. Św. Jozafat biskup biełogorodzki, Rosja, XIX w. Własność prywatna. Rysunek postaci i ozdób na folii poliestrowej melinex wykonany dla potrzeb rekonstrukcji warstwy malarskiej i puncowania na złoceniu. Fot. R. Stasiuk

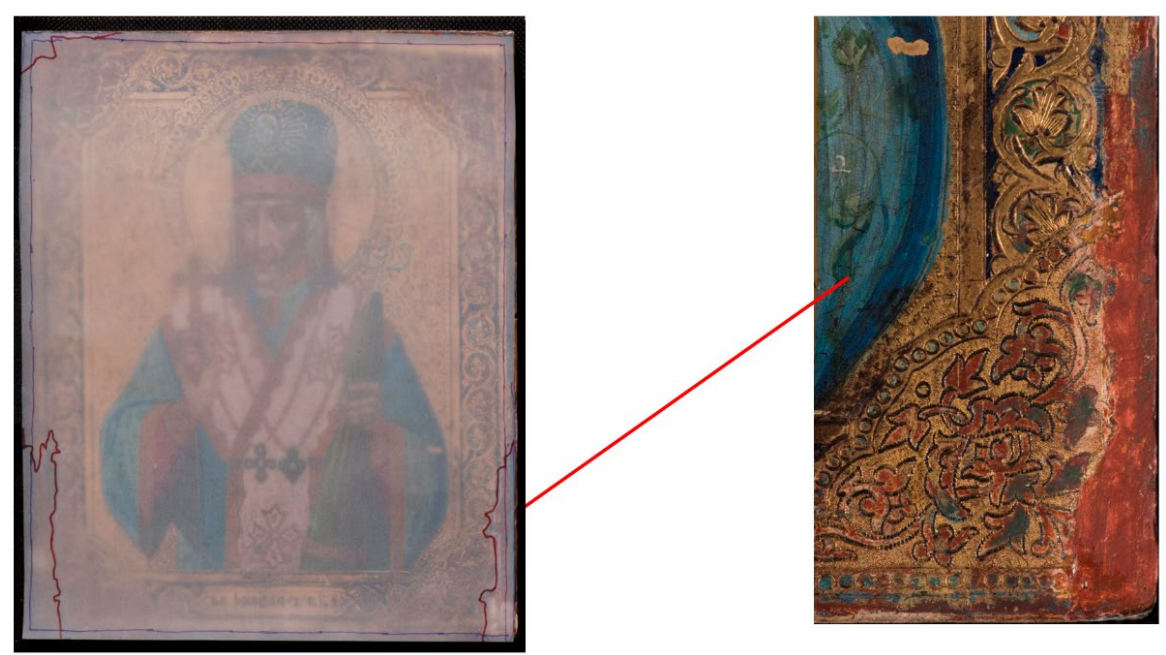

Il. 36. Św. Jozafat biskup biełogorodzki. Miejsca rozległych ubytków warstwy złoceń. Fot. R. Stasiuk 
Przed przystąpieniem do rekonstrukcji przekalkowano rysunek kompozycji (il. 35), celem odwzorowania miejsc, z których usunięto dawny retusz naśladowczy (il. 36). Po uzupełnieniu lewkasu przeniesiono rysunek i wygrawerowano, aby pozostał czytelny po nałożeniu złocenia (wówczas delikatnie „przebija” przez warstwę złota).

Przed położeniem złota ${ }^{27}$ powierzchnię wyszlifowano i pokryto kilkoma cienkimi warstwami czerwonego pulmentu, a po wyschnięciu wypolerowano „wisz pędzlem”. Na tak przygotowaną powierzchnię nakładano płatki złota za pomocą „blat pędzla”. W miejscach, których nie pokrywano barwnym ornamentem, złotu nadano intensywniejszy blask przez wypolerowanie agatem. Następnie odciśnięto głowice punc o różnorodnych wzorach. Na bordiurze w narożach zrekonstruowano stylizowany barwny ornament roślinny w technice imitacji laki ${ }^{28}$ (wykorzystano symetrię ornamentów w narożnikach i powtarzalność motywu wici roślinnej). Uzupełnienia malatury dotyczyły również przedstawienia postaci. Oblicze świętego namalowane jest zdecydowanie bardziej wprawną ręką niż partie szat ${ }^{29}$.

Przy retuszu karnacji należało zastosować, zgodnie z oryginałem, sankir o zielonkawooliwkowej barwie ${ }^{30}$. Sankir stanowi pierwszą warstwę (grisaille) pod karnację i odgrywa bardzo ważną rolę w uzyskaniu barwy wypadkowej po nałożeniu tzw. barwy karnacyjnej, złożonej z ochry, bieli i cynobru. Światła (ożywki) nałożono zgodnie z oryginałem, metodą szrafowania, a światła najwyżej położone (dwiżki) delikatną impastą. Malowano przy użyciu miękkich i elastycznych pędzli z sierści wiewiórki i kuny, w technice tempery.

27 Zastosowano złoto firmy Kremer: płatkowe 24K (nr katalogowy 100250) oraz muszelkowe 23.75 carat, pakowane przez firmę Szmall Sp. z o.o. (do drobnych uzupełnień).

28 Barwny ornament na złocie (imitację laki) wykonano stosując żywicę mastyksową firmy Kremer (gumożywica mastyksowa z Chios w łezkach, nr 60050).

29 „Nie wszyscy w całości samodzielnie wykonywali swe ikony. Na przykład tzw. 'dolicznik' malował tło podstawowym kolorem oraz architekturę i postacie, 'licznik' - malował karnacje twarzy, zaś 'trawiszczik' ornamenty”, Piotr Malec, „O technice malarstwa ikonowego słów kilka”, 1, dostęp 2 sierpnia 2020, https://www.academia.edu/4538796/O_TECHNICE_MALARSTWA_IKONOWEGO_S\%C5\%81\%C3\%93W_KILKA (dostęp: 2.08.2020).

30 „Szkoła nowogrodzka używała sankiru jasnooliwkowego”, P. Malec, „O technice...”, 5. 


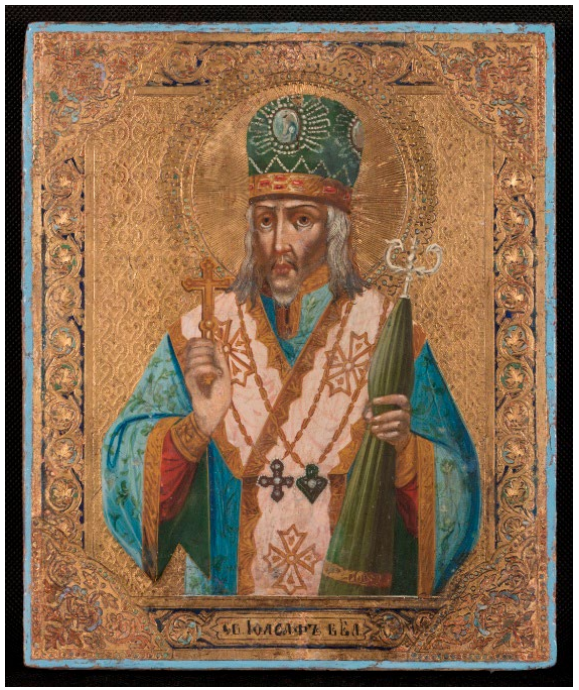

Il. 37. Św. Jozafat biskup biełogorodzki. Lico ikony po zabiegach konserwatorskich. Fot. R. Stasiuk

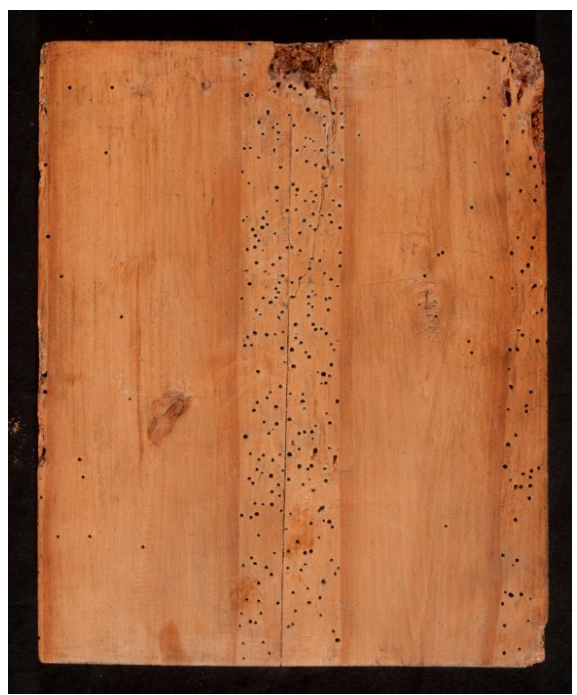

Il. 38. Św. Jozafat biskup biełogorodzki. Odwrocie ikony po zabiegach konserwatorskich. Fot. R. Stasiuk

\section{DYSKUSJA I WNIOSKI}

Zgodnie z głównym zadaniem konserwatorskim, poprawiono stan zachowania ikony przez przywrócenie integralności technologicznej oraz artystyczno-estetycznej sakralnemu przedstawieniu (il. 37, 38). Rozpoznano warsztat nieznanego ikonopisarza ${ }^{31}$.

Na podłożu drewnianym występuje zaprawa gipsowa. Złocenia wykonano płatkami srebrno-złotymi ${ }^{32}$ na czerwonym bolusie. Ikonopisarz do napisania ikony użył w partiach karnacji cynobru, bieli ołowiowej z dodatkiem bieli barytowej oraz czerwieni żelazowej, ugrów i umbry. W partiach szaty i mitry wykorzystał, oprócz ultramaryny i błękitu organicznego, chromiany i błękit pruski. Jak wynika z badań technologicznych, do laserunków na ultramarynie zastosował indygo, a na cynobrze karmin.

31 Ikony nie były sygnowane. „Malarz jest świadom, że tylko ‘użyczył swoich dłoni’ Panu, aby On się objawił, że wypełnił służbę, że poszedł za swoim powołaniem. Oto dlaczego nie podpisuje dzieła: wszystko to, co zostało w nim zawarte nie jest 'jego', lecz należy do wiecznego Boga i Jego Tajemnicy”, Olga Popowa, Engelina Smirnova, Paola Cortesi, Ikony. Ikony różnych kręgów kulturowych od XVI w. po czasy współczesne (Warszawa: Arkady, 1998), 21.

32 Tzw. dwójniakami, stosowanymi w malarstwie ikonowym od XIV w. 
Ikona Św. Jozafat biskup biełogorodzki wykonana jest według kanonu ikonopisania. Badania mikroskopowe wykazały, że jej podłoże sporządzono z drewna olchowego, z desek złożonych z dwóch jednakowych kawałków odwróconych stronami. Głównie drewna tego gatunku używano na podobrazia ikon pisanych w szkole nowogrodzkiej ${ }^{33}$. Bardzo poważne uszkodzenia w tkance podłoża są po części spowodowane tym, że miękkie drewno olchy jest podatne na żerowanie szkodników. Przyczyną występowania w środkowej części podobrazia znacznie większej liczby otworów wylotowych (wydrążonych tam kanałów) mogło być z kolei to, że atakują one głównie drewno zasobne w składniki pokarmowe, jakim jest biel, a złącze desek jest właśnie od strony bieli. Określenie gatunku owadów jedynie na podstawie pozostawionych kanałów jest niemożliwe, najprawdopodobniej należały do gatunku kołatkowatych ${ }^{34}$.

Z przeprowadzonych badań wynika, że malarz tworząc ikonę łączył dawne szlachetne pigmenty mineralne, takie jak ultramaryna i cynober, z później wprowadzonymi chromianami, których przemysłowa produkcja przypada na okres pomiędzy końcem XVIII i pierwszymi dziesięcioleciami XIX wieku ${ }^{35}$. Biorąc to pod uwagę można zatem wnioskować, że działał on w XIX stuleciu.

$Z$ kolei na podstawie analizy warsztatu oraz estetyki malowania należałoby przyjąć, że ikona została napisana w stylu wcześniejszych realizacji, może z końca XVIII w. Od połowy XIX stulecia w ikonopisarstwie łączono pewne elementy tradycyjnego kanonu, takie jak hieratyczny układ postaci, złote tło (światło ikony), niektóre elementy ikonograficzne, z całkowicie zachodnim sposobem malowania ${ }^{36}$. W XIX wieku stosowano już opracowania - głównie karnacji - na modłę zachodnią, z bardziej pogłębionym modelunkiem, bez widocznego szrafowania w półcieniach i światłach, a dwiżki i bliki były bardziej wtapiane w kolor otoczenia (w barwy karnacyjne) ${ }^{37}$. W badanej ikonie obserwujemy tradycyjny wschodni sposób malowania. Reprezentuje ona ty-

33 Malec, „O technice...”, 5.

34 Skonsultowano z dr Elżbietą Pilecką-Pietrusińską, starszym konserwatorem, kierownikiem Laboratorium Muzeum Narodowego w Warszawie (luty 2016 r.).

35 Piotr Rudniewski et al., Pigmenty. Analiza mikrochemiczna i instrumentalna (Warszawa: ASP, 2018), 79, 95, 126.

36 Michał Janocha, Ikony w Polsce. Od średniowiecza do wspótczesności (Warszawa: Arkady, 2016), 39.

37 Szrafowanie staje się w nich mało czytelne, ponieważ poszczególne kreseczki stawiane są bardzo ściśle obok siebie, tworząc jedną plamę malarską. 
powe malarstwo ikonowe, z zachowaniem tradycji pisania ikon zawartych w podlinnikach i dawnych traktatach ${ }^{38}$.

Rozpoznając organoleptycznie i laboratoryjnie materię ikony oraz sposób jej pisania, uzyskano pewne informacje o warsztacie i okresie, w którym powstało dzieło. Podobrazie ikony, podobnie jak w warsztacie nowogrodzkim ${ }^{39}$, wykonane jest z drewna olchy, a zastosowany sankir ${ }^{40}$ ma barwę zielonkawooliwkową. Nie jest to jednoznaczne ze stwierdzeniem, że ikona powstała w tamtym rejonie. Jednak uzyskane wyniki badań z pewnością pomogą w atrybucji i datowaniu podobnych zabytków sztuki.

\section{Bibliografia}

Janocha, Michał. Ikony w Polsce. Od średniowiecza do wspótczesności. Warszawa: Arkady, 2016.

Jarmiłko, Andrzej. „Technologia i technika ruskiego malarstwa ikonowego według podlinników”. Praca magisterska, Uniwersytet Mikołaja Kopernika w Toruniu, 1998.

Kruk, Mirosław Piotr. Ikony XIV-XVI wieku w Muzeum Narodowym w Krakowie. Katalog.

T. 1. Kraków: Muzeum Narodowe w Krakowie, 2019.

Lubryczyńska, Maria. „Współczesne metody konserwacji ikon w Polsce w odniesieniu do rozwiązań stosowanych we wschodniej Europie”. Zeszyty Muzeum Warmii i Mazur 6 (numer monograficzny: Ikona. Sacrum i piękno) (2010): 99-114.

Popowa, Olga, Engelina Smirnova, i Paola Cortesi. Ikony. Ikony różnych kręgów kulturowych od XVI w. po czasy współczesne. Warszawa: Arkady, 1998.

Rudniewski, Piotr, Danuta Jarmińska, Elżbieta Jeżewska, Luiza Kępa, Joanna Kurkowska, Anna Nowicka, Olga Syta, Barbara Wagner, i Aleksandra Wesołowska. Pigmenty. Analiza mikrochemiczna i instrumentalna. Warszawa: ASP, 2018.

Stępień, Danuta. Tempera żółtkowa jako technika w malarstwie według dawnych przekazów i twórczości wybranych współczesnych artystów. Warszawa: ASP, 2010.

38 Wykaz wybranych podlinników zob. Andrzej Jarmiłko, „Technologia i technika ruskiego malarstwa ikonowego według podlinników (praca magisterska, Uniwersytet Mikołaja Kopernika w Toruniu, 1998), 28-35.

39 Wizerunek św. Jozafata biskupa biełogorodzkiego jest przedstawiany na ikonach pochodzących z różnych szkół ikonopisania działających w Rosji w XIX-XX w. W Internecie zamieszczono wiele esejów oraz analiz na temat tych szkół. Rodzaj drewna zastosowanego jako podobrazie praktycznie nie ma znaczenia. https://www.pinterest.co.uk/kivot_studio/\%D1\%81\%D0\%B2\%D1\% 8F\%D1\%82\%D0\%B8\%D1\%82\%D0\%B5\%D0\%BB\%D1\%8C-\%D0\%B8\%D0\%BE\%D0\%B0\%D1\% 81\%D0\%B0\%D1\%84-\%D0\%B1\%D0\%B5\%D0\%BB\%D0\%B3\%D0\%BE\%D1\%80\%D0\%BE\%D0\%B4\%D1\%81\%D0\%BA\%D0\%B8\%D0\%B9/ Dostęp 5 sierpnia 2020.

40 Kolory nakłada się od najciemniejszego do najjaśniejszego. Podkład pod karnację - sankir - w zależności od użytych pigmentów daje odcień oliwkowy lub brązowawy i przebija przez kolejne warstwy malarskie. 
Tradigo, Andrea. Icons and Saints of the Eastern Ortodox Church. Translated by Stephen Sartarelli. Los Angeles: The J. Paul Getty Museum, 2006.

Uspienski, Leonid. Teologia ikony. Tłumaczenie Maria Żurowska. Poznań: Wydawnictwo Polskiej Prowincji Dominikanów „W drodze”, 1993.

Zalewski, Władysław. „Pomiędzy przemalowaniem a preparatem konserwatorskim. Spostrzeżenia dotyczące praktyki konserwatorskiej”. W Sztuka konserwacji. Materiały nadesłane na konferencję z okazji pięćdziesięciolecia Wydziału Konserwacji i Restauracji Dzieł Sztuki ASP w Warszawie 24 i 25 października 1997 r., red. Zofia Jurkowlaniec, 71-77. Warszawa: Drukarnia W\&P Malbork, 1997.

Zeszyty Muzeum Warmii i Mazur 6 (zeszyt monograficzny: Ikona. Sacrum i piękno, red. Grażyna Kobrzeniecka-Sikorska) (2010).

\section{Netografia}

https://grekokatolicy.pl/grekokatolicy/210117/ [życiorys św. Jozafata biskupa biełogorodzkiego]. Dostęp: 21.08.2020.

https://www.google.pl/search?q=ikona+\%C5\%9Bwi\%C4\%99tego+Jozafata\&tbm=isch\&source=iu\&ictx=1\&fir=dfkkCm0_Aew8IM\%252CNAoK6FiY3DS7TM\%252C_\&vet=1\&us$\mathrm{g}=\mathrm{AI} 4$ _kReWtHLvdl536HUGRntfF45P-rPIQ\&sa=X\&ved=2ahUKEwji27Oigq3rAhXIrIsKHUE5CxEQ9QEwA3oECAoQBQ\#imgrc=dfkkCm0_Aew8IM Dostęp: 21.08.2019. https://www.academia.edu/4538796/O_TECHNICE_MALARSTWA_IKONOWEGO_S\%C5\%81\%C3\%93W_KILKA [Piotr Malec O technice malarstwa ikonowego słów kilka]. Dostęp: 2.08.2020.

http://bazhum.muzhp.pl/media//files/Elpis/Elpis-r2010-t12-n21_22/Elpis-r2010-t12-n21_22-s245-289/Elpis-r2010-t12-n21_22-s245-289.pdf [Jarosław Charkiewicz o ikonografii świętych w prawosławiu Elpis 12/21-22, 245-289]. Dostęp: 10.08.2020. https://www.pinterest.co.uk/kivot_studio/\%D1\%81\%D0\%B2\%D1\%8F\%D1\%82\%D0\%B8 \%D1\%82\%D0\%B5\%D0\%BB\%D1\%8C-\%D0\%B8\%D0\%BE\%D0\%B0\%D1\%81\%D0\%B 0\%D1\%84-\%D0\%B1\%D0\%B5\%D0\%BB\%D0\%B3\%D0\%BE\%D1\%80\%D0\%BE\%D0\%B4\%D1\%81\%D0\%BA\%D0\%B8\%D0\%B9/ [przedstawienia św. Josafata biskupa biełogorodzkiego na ikonach]. Dostęp: 5.08.2020.

\section{Autorzy fotografii}

Fotografie badań nieinwazyjnych oraz z przebiegu prac Roman Stasiuk;

Fotografie z badań próbek oraz tabel i wykresów - autorzy badań: dr Katarzyna Wantuch-Jarkiewicz, dr Anna Nowicka, dr Elżbieta Jeżewska, mgr Marek Wróbel. 